\title{
Selected Derivatives of Erythromycin B-In Silico and Anti-Malarial Studies
}

\author{
Pranab K. Bhadra ${ }^{1}$, Rachael N. Magwaza ${ }^{1}$, Niroshini Nirmalan ${ }^{2}$, Sally Freeman ${ }^{1}{ }^{\circledR}$, Jill Barber ${ }^{1} \mathbb{D}$ \\ and Biljana Arsic $1,3, *$ (D)
}

1 Division of Pharmacy and Optometry, School of Health Sciences, University of Manchester, Oxford Road, Manchester M13 9PT, UK; bhadra.pranab@gmail.com (P.K.B.); rachael.magwaza@manchester.ac.uk (R.N.M.); Sally.Freeman@manchester.ac.uk (S.F.); Jill.Barber@manchester.ac.uk (J.B.)

2 School of Science, Engineering \& Environment, University of Salford, Manchester M5 4WT, UK; n.j.nirmalan@salford.ac.uk

3 Department of Chemistry, Faculty of Sciences and Mathematics, University of Nis, Visegradska 33, 18000 Nis, Serbia

* Correspondence: ba432@ymail.com or biljana.arsic@pmf.edu.rs

check for updates

Citation: Bhadra, P.K.; Magwaza, R.N.; Nirmalan, N.; Freeman, S.; Barber, J.; Arsic, B. Selected Derivatives of Erythromycin B-In Silico and Anti-Malarial Studies. Materials 2021, 14, 6980. https://doi.org/10.3390/ ma14226980

Academic Editor: Camelia Ungureanu

Received: 12 October 2021

Accepted: 12 November 2021

Published: 18 November 2021

Publisher's Note: MDPI stays neutral with regard to jurisdictional claims in published maps and institutional affiliations.

Copyright: (c) 2021 by the authors. Licensee MDPI, Basel, Switzerland. This article is an open access article distributed under the terms and conditions of the Creative Commons Attribution (CC BY) license (https:// creativecommons.org/licenses/by/ $4.0 /)$.

\begin{abstract}
Erythromycin A is an established anti-bacterial agent against Gram-positive bacteria, but it is unstable to acid. This led to an evaluation of erythromycin B and its derivatives because these have improved acid stability. These compounds were investigated for their anti-malarial activities, by their in silico molecular docking into segments of the exit tunnel of the apicoplast ribosome from Plasmodium falciparum. This is believed to be the target of the erythromycin A derivative, azithromycin, which has mild anti-malarial activity. The erythromycin B derivatives were evaluated on the multidrug (chloroquine, pyrimethamine, and sulfadoxine)-resistant strain $\mathrm{K} 1$ of $P$. falciparum for asexual growth inhibition on asynchronous culture. The erythromycin B derivatives were identified as active in vitro inhibitors of asexual growth of $P$. falciparum with low micro-molar $\mathrm{IC}_{50}$ values after a $72 \mathrm{~h}$ cycle. 5-Desosaminyl erythronolide B ethyl succinate showed low $\mathrm{IC}_{50}$ of $68.6 \mu \mathrm{M}, d$-erythromycin B $86.8 \mu \mathrm{M}$, and erythromycin B 9-oxime $146.0 \mu \mathrm{M}$ on the multi-drug-resistant $\mathrm{K} 1$ of $P$. falciparum. Based on the molecular docking, it seems that a small number of favourable interactions or the presence of unfavourable interactions of investigated derivatives of erythromycin B with in silico constructed segment from the exit tunnel from the apicoplast of $P$. falciparum is the reason for their weak in vitro anti-malarial activities.
\end{abstract}

Keywords: erythromycin B derivatives; anti-malarial activity; conformational search; molecular docking; interactions

\section{Introduction}

Malaria remains a huge health problem worldwide with 229 million cases and 409,000 registered deaths reported in 2019 [1]. Due to the growing resistance from Southeast Asia to Africa to almost all anti-malarial drugs, it is clear that new therapeutic strategies are essential. Compounds like reversal agents (chemosentisizers, modulating agents) can restore the sensitivity in resistant cells [2,3]. Erythromycin A was first discovered as a reversal agent in multidrug-resistant cancer [4,5]. Antibiotics were found to possess antiplasmodial activity as early as 1940, but they were shown to be less effective and slow acting compared to chloroquine or quinine [3]. Erythromycin A possesses in vitro and in vivo anti-malarial activity [6]. Its anti-malarial action is improved in combination with chloroquine; therefore, its modulating effect is important in chloroquine resistance [3]. Anti-malarial activity has been described for other antibiotics such as co-trimoxazole, quinolones, tigecycline, mirincamycin, ketolides, fusidic acid, and thiopeptides [7]. Based on studies in Africa, co-trimoxazole can be used as an alternative in malaria prophylaxis, for children and adults, HIV (human immunodeficiency viruses) positive or negative patients 
and pregnant women [8-11]. Tigecycline must be administered intravenously; therefore, its use is reserved for patients with severe and complicated malaria, with delayed action similar to doxycycline [7].

The search for more active anti-malarial macrolides than the commercially available anti-malarial drugs has continued. A research group at GSK (GlaxoSmithKline) in Zagreb working on macrolides has published a series of ureas and thioureas of 15-membered azalides with the ureas containing a naphthyl moiety being the most active and $9 a-N$ substituted 15-membered azalides with amide and amine functional groups with improved in vivo efficacy $[12,13]$.

Azithromycin was shown to be a slow anti-malarial targeting parasite apicoplast (an organelle with four membranes containing $35 \mathrm{~kb}$ circular DNA (deoxyribonucleic acid) with replication, RNA (ribonucleic acid) transcription, and RNA-protein translation allowed [14]), giving $\mathrm{IC}_{50}$ in the nanomolar range [15], but better in combination with existing anti-malarial drugs [16].

Therefore, developing a more effective and safer anti-malarial from the class of macrolides is the aim of this research. Here, the in vitro anti-malarial activity of synthesised derivatives of erythromycin B (erythromycin B 9-oxime, 5-desosaminyl erythronolide B ethyl succinate, erythromycin B 2'-[3-(morpholinomethyl)benzoate], erythromycin B 2'-[3-(dimethylaminomethyl)benzoate], and 8- $d$-erythromycin B) (Figure 1), an acid-stable derivative of erythromycin A [17] have been investigated, including the use of molecular docking to give insight regarding the mechanism of action.

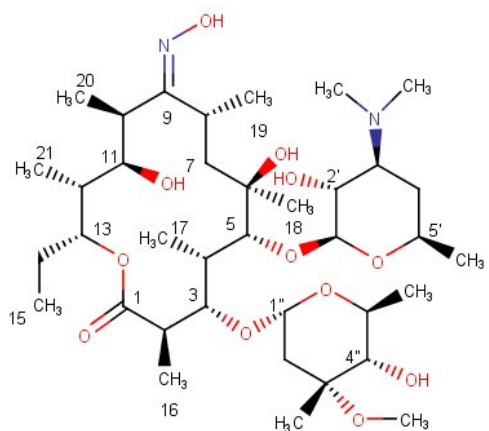

erythromycin B 9-oxime

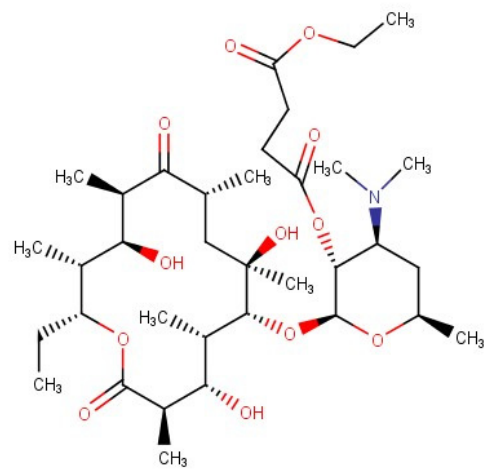

5-desosaminyl erythronolide $B$ ethyl succinate

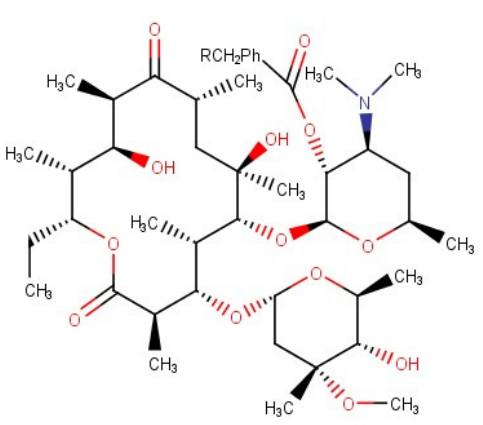

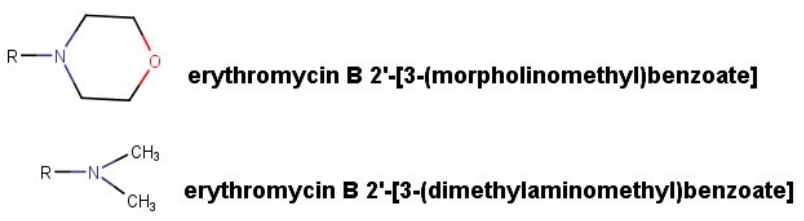

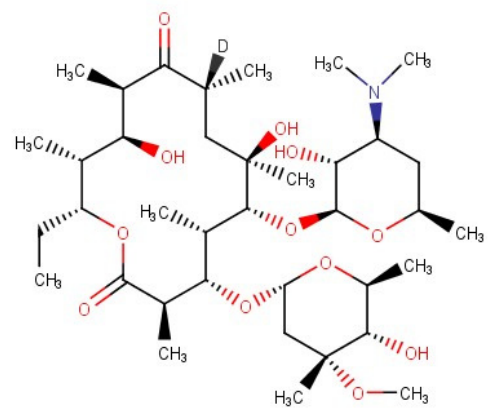

8-d-erythromycin B

Figure 1. Investigated derivatives of erythromycin B against $P$. falciparum $\mathrm{K} 1$ strain. 


\section{Materials and Methods}

\subsection{Instrumentation}

2.1.1. NMR (Nuclear Magnetic Resonance) Spectrometers

Bruker Avance 300 Spectrometer

A Bruker Avance 300 spectrometer (Bruker, Billerica, MA, USA) was operated with an Oxford Instruments magnet (Billerica, MA, USA, magnetic field-7.04 Tesla). In this field, the ${ }^{1} \mathrm{H}$ resonated at $300 \mathrm{MHz}$ and the ${ }^{13} \mathrm{C}$ at $75.47 \mathrm{MHz}$. A $5 \mathrm{~mm}$ QNP (Quattro Nucleus Probe- ${ }^{1} \mathrm{H},{ }^{13} \mathrm{C},{ }^{19} \mathrm{~F},{ }^{31} \mathrm{P}$ ) probe with $\mathrm{Z}$ gradients was used.

\section{Varian Unity 500 Spectrometer}

A Varian Unity 500 NMR spectrometer (Varian Medical Systems, Palo Alto, CA, USA) was operated with an Oxford Instruments magnet, magnetic field-11.74 Tesla. In this field, the ${ }^{1} \mathrm{H}$ resonated at $500 \mathrm{MHz}$. A $5 \mathrm{~mm}$ PFG (Pulse Field Gradient) probe was used. The temperature was controlled using the Varian VT unit with a precision of $\pm 0.1^{\circ} \mathrm{C}$.

\section{Bruker AMX 500 Spectrometer}

A Bruker AMX 500 (Bruker, Billerica, MA, USA) was operated with an Oxford Instruments magnet, magnetic field-11.74 Tesla. Either a TXI-Z (triple nucleus inverse probe with $\mathrm{Z}$ gradients) or a BBI (broad band inverse probe) was used.

The variable temperature unit was used as required. NMR tubes, 507-PP (Wilmad, NJ, USA) were used in all experiments, unless otherwise stated. The spectrometers were used to acquire one-dimensional $\left({ }^{1} \mathrm{H},{ }^{13} \mathrm{C}\right.$, DEPT (Distortionless Enhancement by Polarisation Transfer)-45, DEPT-90 and DEPT-135) and two-dimensional (DQF-COSY, TOCSY, DOSY, $\mathrm{HMQC}$, and HMBC) spectra. The spectra were either acquired in deuterated chloroform $\left(\mathrm{CDCl}_{3}\right)$ referenced to tetramethylsilane (TMS) (Lancaster, UK) as an internal standard or in deuterated buffer (apparent $\mathrm{pH}$ 2.0, 6.0, and 7.0) referenced to 3-(trimethylsilyl)-2,2,3,3tetradeuterio-propionic acid sodium salt (TSP) (Aldrich, Gillingham UK).

\subsubsection{Mass Spectrometer}

Electrospray ionisation-mass spectra (ESI-MS) were acquired on a Micromass Platform mass spectrometer (Waters Corporation, Milford, MA, USA), and the data were analysed using the program PLATFORM with a Masslynx data system. The sample $(10 \mu \mathrm{L})$ was injected using a Hewlett Packard auto-sampler, and the machine was operated at a cone value of $30 \mathrm{eV}$, at $80{ }^{\circ} \mathrm{C}$. For identification purposes, all samples $(0.2 \mathrm{mg})$ were prepared in acetonitrile $(1 \mathrm{~mL})$. For degradation studies, a deuterated Britton-Robinson buffer was used unless otherwise stated. Water was used as the solvent for running the samples unless otherwise stated.

\subsection{3. $\mathrm{pH}$ Meter}

All pH measurements were carried out using a Mettler Delta 320 (Mettler Toledo, Greifensee, Switzerland), equipped with a combination electrode (Gelpas, BDH, Poole, UK). The $\mathrm{pH}$ of the deuterated buffers was measured on the Hanna pH 213 (Hanna Instruments Inc., Woonsocket, RI, USA), equipped with a combination electrode (Gelpas, BDH, Poole, $\mathrm{UK})$ and a temperature probe. Buffer reference standards $(4.00 \pm 0.01,7.00 \pm 0.01$, and $10.00 \pm 0.01$ at $25^{\circ} \mathrm{C}$ ) (Sigma-Aldrich, Saint Louis, MO, USA) were used to calibrate the $\mathrm{pH}$ meters by a two-point calibration method. All $\mathrm{pH}$ measurements were at room temperature and are reported uncorrected.

\subsubsection{Melting Point Apparatus}

All melting points were determined using a Bibby SMP-10 (Stuart Scientific, Staffordshire, UK) melting point apparatus and are reported uncorrected. The samples were placed in a capillary tube and inserted in the melting point apparatus and were heated at a rate of $1^{\circ} \mathrm{C} / \mathrm{min}$ until the compound melted. 


\subsubsection{Thin Layer Chromatography (TLC)}

All the TLC experiments were carried on already-prepared aluminium-backed silica gel $60 \mathrm{~F}_{254}$ (Merck, Darmstadt, Germany) plates without any prior activation. Spots were applied using a $5 \mu \mathrm{L}$ capillary, and EtOAc- $\mathrm{CH}_{3} \mathrm{OH}-25 \% \mathrm{NH}_{3}$ (85:10:5) was used as the mobile phase [18]. The plates were dried in the oven for $1 \mathrm{~min}$ and then were sprayed with $p$-anisaldehyde: sulphuric acid: ethanol mixture (1:1:9). The plates were dried in the oven set at $110{ }^{\circ} \mathrm{C}$ for $5 \mathrm{~min}$, and the $\mathrm{R}_{\mathrm{f}}$ value for each of the compounds was determined.

\subsection{Two-Dimensional NMR Spectroscopy}

\subsubsection{TOCSY and DQF-COSY}

For structural determination, both the TOCSY (Total Correlated Spectroscopy) and the DQF-COSY (Double Quantum Filtered Correlated Spectroscopy) spectra were obtained at ambient temperature on the Varian Unity 500 spectrometer. In the TOCSY experiment, cross-peaks were found for all the protons in the same spin system. The COSY spectrum indicated all the spin-spin coupled protons. For both the experiments, $2048 \times 2048$ complex points were acquired. The spectra were processed using negative line broadening and Gaussian multiplication for resolution enhancement.

\subsubsection{HMQC and HMBC}

HMBC (Heteronuclear Multiple Bond Connectivity) and HMQC (Heteronuclear Multiple Quantum Coherence) spectra were acquired on the Varian Unity 500 spectrometer. An $\mathrm{HMBC}$ spectrum was acquired by using a long-range ${ }^{1} \mathrm{H}_{-}{ }^{13} \mathrm{C} C O S Y$ pulse sequence to give a two-dimensional spectrum with ${ }^{13} \mathrm{C}$ chemical shifts on one axis and ${ }^{1} \mathrm{H}$ chemical shifts on the other. An HMQC indicated single-bond correlation between ${ }^{13} \mathrm{C}$ and the proton to which, it was directly attached.

\subsubsection{DOSY}

Erythromycin B 2'-ethyl succinate was dissolved in deuterated Britton-Robinson buffer at an apparent $\mathrm{pH} 2.0$ to give concentration of $4 \mathrm{mM}$ and was degraded over two hours. The degraded samples were cooled to ambient temperature and a high resolution DOSY (Diffusion-Ordered Spectroscopy) spectrum was acquired using a ONESHOT DOSY pulse sequence. Twelve spectra were acquired, with gradient pulses of $2.9 \mathrm{~ms}$. The FIDDLE (free induction decay deconvolution for line shape enhancement) algorithm [19] was used to correct line shapes using TSP as a reference standard. DOSY spectra were constructed after baseline correction by taking the first echo spectrum and distributing the intensities of the individual signals in the second dimension according to their respective diffusion coefficient $[20,21]$.

\subsection{Synthesis of Erythromycin B Derivatives}

Erythromycin B was a gift from Dr. Warren Mann, Abbott International Division, which was used without further purification. Acetone (GPR grade, BDH, Poole, UK) dried over anhydrous sodium sulphate $\left(\mathrm{Na}_{2} \mathrm{SO}_{4}\right)$ was used as a solvent in most syntheses, unless stated otherwise. The water work-up refers to washing the organic layer with water $(2 \times 50 \mathrm{~mL})$ and $50 \mathrm{~mL}$ brine (saturated sodium chloride solution).

\subsubsection{Synthesis of Erythromycin B Oxime}

The First Method

This method was adapted from Gasc et al. (1991) [22]. Erythromycin B (5.0 g) was dissolved in $50 \mathrm{~mL}$ methanol (GPR grade, BDH, UK, previously dried over sodium sulphate) followed by addition of $2.46 \mathrm{~mL}$ triethylamine and $2.46 \mathrm{~g}$ hydroxylamine hydrochloride (Sigma-Aldrich, Burlington, MA, USA). The mixture was refluxed for $24 \mathrm{~h}$. After complete dissolution, the progressive crystallisation of erythromycin B oxime hydrochloride was observed. The reaction mixture was cooled to $2{ }^{\circ} \mathrm{C}$ for $1 \mathrm{~h}$. The crystals were separated and washed three times with $2.5 \mathrm{~mL}$ cooled methanol. To the suspension of erythromycin 
oxime hydrochloride in $15 \mathrm{~mL}$ methanol $\left(20^{\circ} \mathrm{C}\right), 3.26 \mathrm{~mL}$ of ammonium hydroxide solution $(20 \%)$ was added. After stirring for $30 \mathrm{~min}, 3.26 \mathrm{~mL}$ of water was added to the solution to give $1.8 \mathrm{~g}$ of erythromycin B oxime. Yield 36.0\%, m.p. $170-174{ }^{\circ} \mathrm{C},{ }^{1} \mathrm{H} \mathrm{NMR}\left(\mathrm{CDCl}_{3}\right.$, $300 \mathrm{MHz}): \delta 0.87\left(\mathrm{CH}_{3}-21, \mathrm{~d}, J=7.1 \mathrm{~Hz}\right), \delta 0.87\left(\mathrm{CH}_{3}-15, \mathrm{t}, J=7.3 \mathrm{~Hz}\right), \delta 1.05\left(\mathrm{CH}_{3}-20, \mathrm{~d}\right.$, $J=6.8 \mathrm{~Hz}), \delta 1.12\left(\mathrm{CH}_{3}-17, \mathrm{~d}, J=7.5 \mathrm{~Hz}\right), \delta 1.13\left(\mathrm{CH}_{3}-19, \mathrm{~d}, J=7.1 \mathrm{~Hz}\right), \delta 1.18\left(\mathrm{CH}_{3}-16, \mathrm{~d}\right.$, $J=7.3 \mathrm{~Hz}), \delta 1.21\left(\mathrm{CH}_{3}-6^{\prime}, \mathrm{d}, J=6.0 \mathrm{~Hz}\right), \delta 1.21\left(\mathrm{CH}_{3}-7^{\prime \prime}, \mathrm{s}\right), \delta 1.29\left(\mathrm{CH}_{3}-6^{\prime \prime}, \mathrm{d}, J=6.2 \mathrm{~Hz}\right)$,

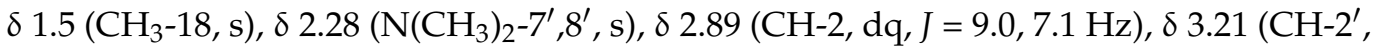
$\mathrm{dd}, J=10.3,7.5 \mathrm{~Hz}), \delta 3.31\left(\mathrm{OCH}_{3}-8^{\prime \prime}, \mathrm{s}\right), \delta 3.49\left(\mathrm{CH}-5^{\prime}, \mathrm{m}\right), \delta 3.6(\mathrm{CH}-5, \mathrm{~d}, J=7.5 \mathrm{~Hz})$, $\delta 3.63(\mathrm{CH}-11, \mathrm{~d}, J=10.0 \mathrm{~Hz}), \delta 4.0\left(\mathrm{CH}^{\prime}{ }^{\prime \prime}, \mathrm{dq}, J=9.5,6.2 \mathrm{~Hz}\right), \delta 4.06(\mathrm{CH}-3, \mathrm{dd}, J=9.0$, $1.5 \mathrm{~Hz}), \delta 4.43\left(\mathrm{CH}^{-1}{ }^{\prime}, \mathrm{d}, J=7.3 \mathrm{~Hz}\right), \delta 4.93\left(\mathrm{CH}^{\prime \prime}{ }^{\prime \prime}, \mathrm{d}, J=4.7 \mathrm{~Hz}\right), \delta 5.42(\mathrm{CH}-13, \mathrm{dd}, J=9.6$, $4.6 \mathrm{~Hz}) ; \mathrm{m} / z \mathrm{z} 33[\mathrm{M}+\mathrm{H}]^{+} ; \mathrm{R}_{\mathrm{f}} 0.36\left(\mathrm{CH}_{2} \mathrm{Cl}_{2}-\mathrm{CH}_{3} \mathrm{OH}-25 \% \mathrm{NH}_{3}, 90: 9: 1.5\right)$ [18]; Anal. Calcd for $\mathrm{C}_{37} \mathrm{H}_{68} \mathrm{~N}_{2} \mathrm{O}_{12}$ (\%): C 60.62, H 9.37, N 3.82. Found (\%): C 60.42, H 9.29, N 3.71.

The Second Method

This method was adapted from Watanabe et al. (1993) [23]. Erythromycin B (5.0 g), $2.49 \mathrm{~g}$ anhydrous sodium acetate (Fisher Scientific, Loughborough, UK) and $1.75 \mathrm{~g}$ hydroxylamine hydrochloride (Sigma-Aldrich, Burlington, MA, USA) were added to 20 $\mathrm{mL}$ methanol, and the suspension was stirred at room temperature for 6 days and then refluxed for $30 \mathrm{~min}$. The reaction mixture was concentrated in vacuo to about half the original volume and poured into $10 \mathrm{~mL}$ water. The resulting crystals were filtered, triturated successively with water, saturated $\mathrm{NaHCO}_{3}$ solution and water, and then filtered. Crystallisation from dichloromethane- $n$-hexane gave $3.46 \mathrm{~g}$ of erythromycin $\mathrm{B}$ oxime. Yield 69.2\%, m.p. $172-174{ }^{\circ} \mathrm{C},{ }^{1} \mathrm{H}$ NMR $\left(\mathrm{CDCl}_{3}, 500 \mathrm{MHz}\right): \delta 0.89\left(\mathrm{CH}_{3}-21, \mathrm{~d}, J=7.1 \mathrm{~Hz}\right), \delta 0.88$ $\left(\mathrm{CH}_{3}-15, \mathrm{t}, J=7.3 \mathrm{~Hz}\right), \delta 1.03\left(\mathrm{CH}_{3}-20, \mathrm{~d}, J=6.8 \mathrm{~Hz}\right), \delta 1.03\left(\mathrm{CH}_{3}-16, \mathrm{~d}, J=7.3 \mathrm{~Hz}\right), \delta 1.12$ $\left(\mathrm{CH}_{3}-17, \mathrm{~d}, J=7.5 \mathrm{~Hz}\right), \delta 1.18\left(\mathrm{CH}_{3}-19, \mathrm{~d}, J=7.1 \mathrm{~Hz}\right), \delta 1.25\left(\mathrm{CH}_{3}-6^{\prime}, \mathrm{d}, J=6.0 \mathrm{~Hz}\right), \delta 1.25$

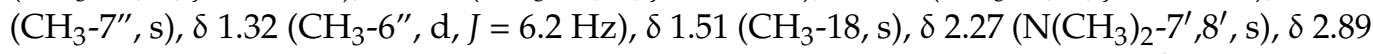
$(\mathrm{CH}-2, \mathrm{dq}, J=9.0,7.1 \mathrm{~Hz}), \delta 3.0(\mathrm{CH}-10, \mathrm{dq}, J=6.8,1.1 \mathrm{~Hz}), \delta 3.23\left(\mathrm{CH}^{\prime}{ }^{\prime}, \mathrm{dd}, J=10.3\right.$, $7.5 \mathrm{~Hz}), \delta 3.33\left(\mathrm{OCH}_{3}-8^{\prime \prime}, \mathrm{s}\right), \delta 3.49\left(\mathrm{CH}-5^{\prime}, \mathrm{m}\right), \delta 3.58(\mathrm{CH}-5, \mathrm{~d}, J=7.5 \mathrm{~Hz}), \delta 3.59(\mathrm{CH}-11$, bd, $J=10.0 \mathrm{~Hz}), \delta 4.0\left(\mathrm{CH}-5^{\prime \prime}, \mathrm{dq}, J=9.5,6.2 \mathrm{~Hz}\right), \delta 4.06(\mathrm{CH}-3, \mathrm{dd}, J=9.0,1.5 \mathrm{~Hz}), \delta 4.42$ $\left(\mathrm{CH}-1^{\prime}, \mathrm{d}, J=7.3 \mathrm{~Hz}\right), \delta 4.92\left(\mathrm{CH}^{\prime \prime}{ }^{\prime \prime}, \mathrm{d}, J=4.7 \mathrm{~Hz}\right), \delta 5.42(\mathrm{CH}-13, \mathrm{dd}, J=9.6,4.6 \mathrm{~Hz}) ; \mathrm{m} / z$ $733[\mathrm{M}+\mathrm{H}]^{+} ; \mathrm{R}_{\mathrm{f}} 0.23\left(\mathrm{CH}_{2} \mathrm{Cl}_{2}-\mathrm{CH}_{3} \mathrm{OH}-25 \% \mathrm{NH}_{3}, 90: 9: 1.5\right)$; Anal. Calcd for $\mathrm{C}_{37} \mathrm{H}_{68} \mathrm{~N}_{2} \mathrm{O}_{12}$ (\%): C 60.62, H 9.37, N 3.82. Found (\%): C 60.51, H 9.63, N 3.66.

\subsubsection{Synthesis of Erythromycin B $2^{\prime}$-(3-chloromethylbenzoate) (EBCMB)}

EBCMB acts as a starting material for all the erythromycin $2^{\prime}-(N$-substituted $3-$ or 4 aminomethylbenzoate) esters. It was prepared by adapting the procedure used by Jensen et al. (1990) [24]. 3-Chloromethylbenzoyl chloride (1.25 mL, Sigma-Aldrich, Burlington, MA, USA) in $5 \mathrm{~mL}$ acetone was added dropwise to a mixture of erythromycin $\mathrm{B}(5 \mathrm{~g})$ and $1 \mathrm{~g} \mathrm{NaHCO}_{3}$ in $200 \mathrm{~mL}$ acetone. The resulting solution was stirred at room temperature overnight. The residue was stirred with $100 \mathrm{~mL}$ phosphate buffer ( $\mathrm{pH}$ 6.5) for $15 \mathrm{~min}$ followed by a water work-up. The organic layer was dried in vacuo, and the crystalline product was recrystallised from ethyl acetate. Yield $89.4 \%$, m.p. $192-194{ }^{\circ} \mathrm{C},{ }^{1} \mathrm{H}$ NMR $\left(\mathrm{CDCl}_{3}, 500 \mathrm{MHz}\right): \delta 0.72\left(\mathrm{CH}_{3}-17, \mathrm{~d}, J=7.1 \mathrm{~Hz}\right), \delta 0.76\left(\mathrm{CH}_{3}-21, \mathrm{~d}, J=7.5 \mathrm{~Hz}\right), \delta 0.82$ $\left(\mathrm{CH}_{3}-15, \mathrm{t}, J=7.4 \mathrm{~Hz}\right), \delta 0.96\left(\mathrm{CH}_{3}-20, \mathrm{~d}, J=6.8 \mathrm{~Hz}\right), \delta 1.12\left(\mathrm{CH}_{3}-19, \mathrm{~d}, \mathrm{~J}=7.1 \mathrm{~Hz}\right), \delta 1.16$ $\left(\mathrm{CH}_{3}-16, \mathrm{~d}, J=7.1 \mathrm{~Hz}\right), \delta 1.26\left(\mathrm{CH}_{3}-6^{\prime}, \mathrm{d}, J=6.2 \mathrm{~Hz}\right), \delta 1.27\left(\mathrm{CH}_{3}-7^{\prime \prime}, \mathrm{s}\right), \delta 1.29\left(\mathrm{CH}_{3}-6^{\prime \prime}, \mathrm{d}\right.$,

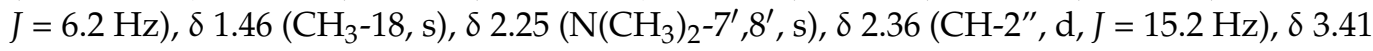
$\left(\mathrm{OCH}_{3}-8^{\prime \prime}, \mathrm{s}\right), \delta 3.55(\mathrm{CH}-5, \mathrm{~d}, 7.5 \mathrm{~Hz}), \delta 3.69(\mathrm{CH}-11, \mathrm{~d}, J=9.8 \mathrm{~Hz}), \delta 4.0\left(\mathrm{CH}-5^{\prime \prime}\right.$, obs $)$, $\delta 4.61\left(\mathrm{CH}_{2}-16^{\prime}, \mathrm{s}\right), \delta 4.70\left(\mathrm{CH}_{-1}^{\prime}, \mathrm{d}, J=7.5 \mathrm{~Hz}\right), \delta 4.86\left(\mathrm{CH}^{\prime} 1^{\prime \prime}, \mathrm{d}, J=4.5 \mathrm{~Hz}\right), \delta 5.02\left(\mathrm{CH}-2^{\prime}\right.$, $\mathrm{dd}, J=10.5,7.5 \mathrm{~Hz}), \delta 5.28(\mathrm{CH}-13, \mathrm{dd}, J=9.4,4.8 \mathrm{~Hz}), \delta 7.42\left(\mathrm{CH}-12^{\prime}, \mathrm{dd}, J=7.7 \mathrm{~Hz}\right), \delta 7.57$ $\left(\mathrm{CH}-13^{\prime}, \mathrm{d}, J=7.7 \mathrm{~Hz}\right), \delta 7.96\left(\mathrm{CH}_{-11}^{\prime}, \mathrm{d}, J=7.7 \mathrm{~Hz}\right), \delta 8.05\left(\mathrm{CH}-15^{\prime}, \mathrm{s}\right) ; \mathrm{m} / z 870[\mathrm{M}+\mathrm{H}]^{+}$; $\mathrm{R}_{\mathrm{f}} 0.62$ (EtOAc- $\left.\mathrm{CH}_{3} \mathrm{OH}-25 \% \mathrm{NH}_{3}, 85: 10: 5\right)$; Anal. Calcd for $\mathrm{C}_{45} \mathrm{H}_{72} \mathrm{NO}_{13} \mathrm{Cl}(\%)$ : C 62.08, H 8.35, N 1.60. Found (\%): C 62.05, H 8.40, N 1.59. 


\subsubsection{Synthesis of Erythromycin B 2'-[3-(morpholinomethyl)benzoate] (EBMMB)}

A mixture of erythromycin B 2'-(3-chloromethylbenzoate) $(1 \mathrm{~g})$, morpholine $(0.2 \mathrm{~mL})$ and sodium iodide $(20 \mathrm{mg})$ in $75 \mathrm{~mL}$ acetone was refluxed for $20 \mathrm{~h}$. Following the water work-up the organic layer was reduced to dryness in vacuo. The colourless crystals of EBMMB were recrystallised from ethyl acetate. Yield 83\%, m.p. $126-128{ }^{\circ} \mathrm{C},{ }^{1} \mathrm{H}$ NMR $\left(\mathrm{CDCl}_{3}, 500 \mathrm{MHz}\right): \delta 0.7\left(\mathrm{CH}_{3}-17, \mathrm{~d}, J=7.1 \mathrm{~Hz}\right), \delta 0.76\left(\mathrm{CH}_{3}-21, \mathrm{~d}, J=7.5 \mathrm{~Hz}\right), \delta 0.84$ $\left(\mathrm{CH}_{3}-15, \mathrm{t}, J=7.4 \mathrm{~Hz}\right), \delta 0.96\left(\mathrm{CH}_{3}-20, \mathrm{~d}, J=6.8 \mathrm{~Hz}\right), \delta 1.13\left(\mathrm{CH}_{3}-19, \mathrm{~d}, J=7.3 \mathrm{~Hz}\right), \delta 1.17$ $\left(\mathrm{CH}_{3}-16, \mathrm{~d}, J=6.8 \mathrm{~Hz}\right), \delta 1.26\left(\mathrm{CH}_{3}-6^{\prime}, \mathrm{d}, J=6.2 \mathrm{~Hz}\right), \delta 1.28\left(\mathrm{CH}_{3}-7^{\prime \prime}, \mathrm{s}\right), \delta 1.30\left(\mathrm{CH}_{3}-6^{\prime \prime}, \mathrm{d}\right.$,

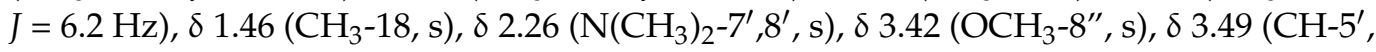
m), $\delta 3.58(\mathrm{CH}-5, \mathrm{~d}, J=7.5 \mathrm{~Hz}), \delta 3.69(\mathrm{CH}-11, \mathrm{~d}, J=10.0 \mathrm{~Hz}), \delta 4.0\left(\mathrm{CH}-5{ }^{\prime \prime}, \mathrm{dq}, J=9.4\right.$, $6.2 \mathrm{~Hz}), \delta 4.0(\mathrm{CH}-3, \mathrm{dd}, J=9.0,1.5 \mathrm{~Hz}), \delta 4.70\left(\mathrm{CH}-1^{\prime}, \mathrm{d}, J=7.5 \mathrm{~Hz}\right), \delta 4.87\left(\mathrm{CH}-1^{\prime \prime}, \mathrm{d}\right.$, $J=4.9 \mathrm{~Hz}), \delta 5.04\left(\mathrm{CH}-2^{\prime}, \mathrm{dd}, J=10.5,7.5 \mathrm{~Hz}\right), \delta 5.29(\mathrm{CH}-13, \mathrm{dd}, J=9.2,4.3 \mathrm{~Hz}), \delta 7.37$ $\left(\mathrm{CH}-12^{\prime}, \mathrm{dd}, J=7.7 \mathrm{~Hz}\right), \delta 7.54\left(\mathrm{CH}-13^{\prime}, \mathrm{d}, J=7.7 \mathrm{~Hz}\right), \delta 7.90\left(\mathrm{CH}-11^{\prime}, \mathrm{d}, J=7.7 \mathrm{~Hz}\right), \delta 7.94$ $\left(\mathrm{CH}-15^{\prime}, \mathrm{s}\right) ; \mathrm{m} / z$ $921[\mathrm{M}+\mathrm{H}]^{+} ; \mathrm{R}_{\mathrm{f}} 0.61$ (EtOAc- $\left.\mathrm{CH}_{3} \mathrm{OH}-25 \% \mathrm{NH}_{3}, 85: 10: 5\right)$; Anal. Calcd for $\mathrm{C}_{49} \mathrm{H}_{80} \mathrm{~N}_{2} \mathrm{O}_{14}$ (\%): C 64.02, H 8.79, N 4.57. Found (\%): C 63.84, H 8.71, N 4.51.

2.3.4. Synthesis of Erythromycin B 2'-[3-(dimethylaminomethyl)benzoate] (EBDMAMB)

A mixture of erythromycin B 2'-(3-chloromethylbenzoate) $(2 \mathrm{~g})$, dimethylamine $(3.9 \mathrm{~mL}$ of a $33 \%$ solution in ethanol) (Fluka, Loughborough, UK), and sodium iodide $(20 \mathrm{mg})$ in $100 \mathrm{~mL}$ acetone (previously dried over anhydrous $\mathrm{Na}_{2} \mathrm{SO}_{4}$ ) was refluxed for $20 \mathrm{~h}$. Following the water work-up, the organic layer was reduced to dryness in vacuo, and the colourless crystals of EBDMAMB were recrystallised from ethyl acetate. Yield $65 \%$, m.p.128-130 ${ }^{\circ} \mathrm{C}$, ${ }^{1} \mathrm{H} \mathrm{NMR}\left(\mathrm{CDCl}_{3}, 500 \mathrm{MHz}\right): \delta 0.71\left(\mathrm{CH}_{3}-17, \mathrm{~d}, J=7.1 \mathrm{~Hz}\right), \delta 0.73\left(\mathrm{CH}_{3}-21, \mathrm{~d}, J=7.5 \mathrm{~Hz}\right)$, $\delta 0.82\left(\mathrm{CH}_{3}-15, \mathrm{t}, J=7.4 \mathrm{~Hz}\right), \delta 0.96\left(\mathrm{CH}_{3}-20, \mathrm{~d}, J=6.8 \mathrm{~Hz}\right), \delta 1.12\left(\mathrm{CH}_{3}-19, \mathrm{~d}, J=7.1 \mathrm{~Hz}\right)$, $\delta 1.16\left(\mathrm{CH}_{3}-16, \mathrm{~d}, J=7.1 \mathrm{~Hz}\right), \delta 1.26\left(\mathrm{CH}_{3}-6^{\prime}, \mathrm{d}, J=6.2 \mathrm{~Hz}\right), \delta 1.27\left(\mathrm{CH}_{3}-7^{\prime \prime}, \mathrm{s}\right), \delta 1.30\left(\mathrm{CH}_{3}-6^{\prime \prime}\right.$,

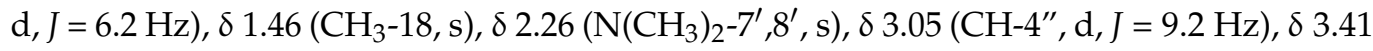
$\left(\mathrm{OCH}_{3}-8^{\prime \prime}, \mathrm{s}\right), \delta 3.54(\mathrm{CH}-5, \mathrm{~d}, J=7.5 \mathrm{~Hz}), \delta 3.55\left(\mathrm{CH}-5^{\prime}, \mathrm{m}\right), \delta 3.69(\mathrm{CH}-11, \mathrm{~d}, J=9.6 \mathrm{~Hz})$, $\delta 3.98(\mathrm{CH}-3, \mathrm{dd}, J=9.0,1.5 \mathrm{~Hz}), \delta 4.0\left(\mathrm{CH}-5^{\prime \prime}, \mathrm{dq}, J=9.0,6.2 \mathrm{~Hz}\right), \delta 4.61\left(\mathrm{CH}-16^{\prime}, \mathrm{s}\right), \delta 4.7$ $\left(\mathrm{CH}_{-1}{ }^{\prime}, \mathrm{d}, J=7.5 \mathrm{~Hz}\right), \delta 4.87\left(\mathrm{CH}-1^{\prime \prime}, \mathrm{d}, J=4.5 \mathrm{~Hz}\right), \delta 5.04\left(\mathrm{CH}-2^{\prime}, \mathrm{dd}, J=10.5,7.5 \mathrm{~Hz}\right), \delta 5.28$ $(\mathrm{CH}-13, \mathrm{dd}, J=9.4,4.3 \mathrm{~Hz}), \delta 7.39\left(\mathrm{CH}-12^{\prime}, \mathrm{dd}, J=7.7 \mathrm{~Hz}\right), \delta 7.54\left(\mathrm{CH}-13^{\prime}, \mathrm{bd}, J=7.6 \mathrm{~Hz}\right)$, $\delta 7.91\left(\mathrm{CH}-11^{\prime}, \mathrm{d}, J=7.6 \mathrm{~Hz}\right), \delta 7.96\left(\mathrm{CH}-15^{\prime}, \mathrm{s}\right) ; \mathrm{m} / z \mathrm{z} 89[\mathrm{M}+\mathrm{H}]^{+} ; \mathrm{R}_{\mathrm{f}} 0.3\left(\mathrm{EtOAc}^{-\mathrm{CH}_{3} \mathrm{OH}-}\right.$ $\left.25 \% \mathrm{NH}_{3}, 85: 10: 5\right)$; Anal. Calcd for $\mathrm{C}_{47} \mathrm{H}_{78} \mathrm{~N}_{2} \mathrm{O}_{13}$ (\%): C 64.20, H 8.96, N 3.18. Found (\%): C 64.49, H 8.98, N 3.19.

\subsubsection{Synthesis of 5-Desosaminyl Erythronolide B Ethyl Succinate}

5-Desosaminyl erythronolide B ethyl succinate was made from erythromycin B ethyl succinate under similar conditions previously described $[17,25,26]$.

\subsubsection{Synthesis of Erythromycin B Enol Ether}

Erythromycin B enol ether was made from erythromycin B under conditions previously described [25].

\subsubsection{Synthesis of 8- $d$-erythromycin B (8D-EB)}

8-d-erythromycin $\mathrm{B}$ was made from erythromycin $\mathrm{B}$ enol ether under conditions previously described [27].

\subsection{In Vitro Determination of the Anti-Malarial Activity of Selected Erythromycin B Derivatives}

2.4.1. Cultivation of P. falciparum Parasite

Chloroquine, pyrimethamine and sulfadoxine-resistant $\mathrm{K} 1$ strain of $P$. falciparum was cultured with RPMI (Roswell Park Memorial Institute) 1640 media containing $25 \mathrm{mM}$ (2-hydroxyethyl) piperazine- $N^{\prime}$-(2-ethane-sulfonic acid) (HEPES) and $0.3 \mathrm{~g} / \mathrm{L}$ L-glutamine (Gibco, Life Technologies, Renfrew, UK). The medium was supplemented with sterile filtered $2.5 \mathrm{~g}$ AlbuMax (Sigma-Aldrich, Saint Louis, MO, USA), $2.5 \mathrm{~mL}$ hypoxanthine (Sigma-Aldrich, Saint Louis, MO, USA), 2.5 mL 40\% glucose (Dextrose Anhydrous, Fisher 
Scientific, UK) and $0.5 \mathrm{~mL}$ gentamycin (Sigma-Aldrich, Saint Louis, MO, USA). Human erythrocytes served as host cells. Cultures were maintained at $37^{\circ} \mathrm{C}$ under the gas mixture of $5 \% \mathrm{CO}_{2}$ and $5 \% \mathrm{O}_{2}$ in $\mathrm{N}_{2}$ gas mixture (BOC Limited, Guildford, UK).

\subsubsection{Synchronisation of $\mathrm{K} 1$ P. falciparum}

The K1 strain of $P$. falciparum was cultivated until $\geq 8 \%$ parasitaemia was obtained, with neat prevalence of ring stages. The culture was then transferred to a falcon tube and centrifuged at $3500 \mathrm{rpm}$ for $5 \mathrm{~min}$ at $20^{\circ} \mathrm{C}$. Supernatant was removed, and the pellet was re-suspended in $5 \mathrm{~mL}$ of aqueous $5 \%$ sorbitol at room temperature for $5 \mathrm{~min}$ and further centrifuged as before. The supernatant was removed, and the pellet was washed 3 times with complete media before setting up a new culture. The pellet was re-suspended in complete media with enough purified 50\% RBCs (red blood cells) to obtain 5\% final haematocrit.

\subsubsection{Determination of $\mathrm{IC}_{50}$ in $\mathrm{K} 1 P$. falciparum}

Here, $1 \%$ infected RBCs with $P$. falciparum $\mathrm{K} 1$ strain at ring stage were exposed to 9 dilutions at concentrations of $3.05 \mathrm{nM}-200 \mu \mathrm{M}$ (4-fold serial dilution) of compounds from $50 \mathrm{mM}$ stock solutions. $100 \mu \mathrm{L}$ of culture volume was added in 96-well plates with $100 \mu \mathrm{L}$ drug dilutions. Untreated infected RBCs served as positive control while the uninfected RBCs was a negative control. The plates were incubated for $72 \mathrm{~h}$ at $37^{\circ} \mathrm{C}, 5 \% \mathrm{CO}_{2}$, and $5 \%$ $\mathrm{O}_{2}$ in $\mathrm{N}_{2}$. Following the incubation, $150 \mu \mathrm{L}$ of media was carefully removed, and $150 \mu \mathrm{L}$ of SYBR (Synergy Brands) Green solution (prepared by adding $2 \mu \mathrm{L}$ of 10,000 X SYBR Green in $4 \mathrm{~mL}$ of phosphate buffer saline (PBS)) was added to each well. The plates were kept in the dark for $45 \mathrm{~min}$ at room temperature. The fluorescence intensity was measured using a microplate reader (Genius Tecan) set at $485 \mathrm{~nm}$ excitation and $535 \mathrm{~nm}$ emission wavelengths. Chloroquine was included as a control drug.

The $\mathrm{IC}_{50}$ values were determined using Graph Pad Prism 5.0. Values were calculated using non-linear regression by using log-transformed drug concentration plotted against dose-response. Parasitaemia was calculated and normalised relative to response on the controls (cultures without drug).

\subsection{Conformational Search Studies}

\subsubsection{Unconstrained Conformational Search}

Conformational analysis of selected derivatives of erythromycin B (erythromycin B 9-oxime, 5-desosaminyl erythronolide B ethyl succinate, erythromycin B 2'-[3-(morpholinome thyl)benzoate], erythromycin B 2'-[3-(dimethylaminomethyl)benzoate], and 8- $d$-erythromycin B) was performed using Macromodel under Schrodinger Suite 2021-1 and Maestro v. 12.7.156 as the interface. Chloroform was used as a solvent. The minimisations were first performed with charges from force field, cut off was extended, minimisation method was TNCG (Truncated Newton Conjugate Gradient), and the number of maximum iterations was set to 10,000, with the gradient convergence, and its threshold 0.05. Conformational search torsional sampling was MCMM (Monte Carlo multiple minimum) with automatic setup during the calculation, and torsion sampling options: intermediate. The maximum number of steps was 10,000, with 100 steps per rotatable bond. Number of structures to be saved for each search was 100, energy window for saving structures $21 \mathrm{~kJ} / \mathrm{mol}$, and maximum atom deviation cut off $0.5 \AA$.

\subsubsection{Constrained Conformational Search}

The constrained conformational search was performed for erythromycin B 2'-[3(dimethylaminomethyl)benzoate] in chloroform using Macromodel and Maestro v. 12.7.156 as the interface under Schrodinger Suite 2021-1. The distance H4-H11 was constrained to $2.5 \pm 0.3 \AA$ and $\mathrm{H} 5-\mathrm{H} 18$ to $2.5 \pm 0.3 \AA$ starting from the global minimum of the unconstrained conformational search for this compound. 
Conformational search torsional sampling was MCMM with automatic setup during the calculation and torsion sampling options: intermediate. The maximum number of steps was 10,000, with 100 steps per rotatable bond. Number of structures to be saved for each search was 100, energy window for saving structures $21 \mathrm{~kJ} / \mathrm{mol}$, and maximum atom deviation cut off $0.5 \AA$.

\subsection{Molecular Docking Studies}

Molecular docking studies were performed using the Patchdock web server with the Patchdock molecular docking algorithm based on shape complementarity principles [28-30]. The input is set consisting of the pdb files of the receptor molecule and the ligand molecule. The pdb files of the ligand molecules consisted of folded-out structures obtained in the unconstrained conformational search for all investigated erythromycin B derivatives, except erythromycin B 2'-[3-(dimethylaminomethyl)benzoate], where we used the global minimum of the constrained conformational search. The output is a list of the potential complexes sorted by the shape complementarity principles.

Ten best results from docking analysis using Patchdock algorithm were submitted to FireDock for refinement [31,32].

Visualisation of the results and the formation of 2D diagrams were performed using Discovery Studio 2021 Client (Dessault Systems Biovia Corp., San Diego, CA, USA).

\section{Results and Discussion}

\subsection{Synthesis of N-Substituted 2'-(3-aminomethylbenzoate) Esters of Erythromycin B}

$\mathrm{N}$-substituted 2'-(3-aminomethylbenzoate) esters of erythromycin B were synthesised in two steps. In the first step, erythromycin B was esterified at C-2' with 3-chloromethylbenzoyl chloride. In the second step, the product erythromycin B 2'-[3-chloromethylbenzoate] was heated at reflux with the appropriate amine $(\mathrm{R})$ in the presence of sodium iodide as a catalyst (Scheme 1) [33].

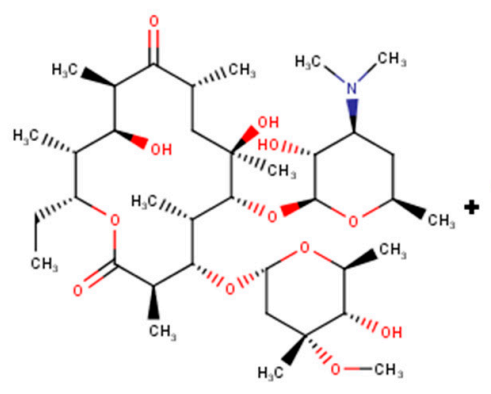<smiles>O=C(Cl)c1cccc(CCl)c1</smiles>

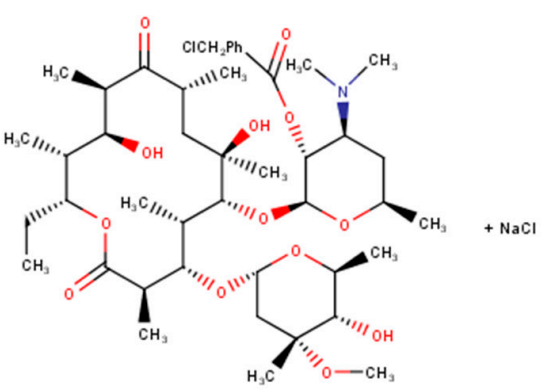

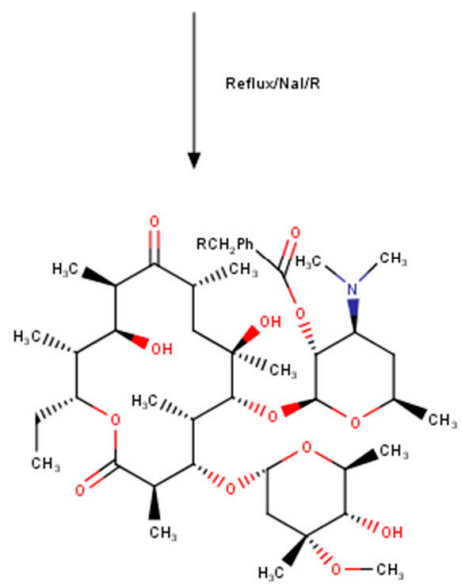

Scheme 1. Synthesis of $N$-substituted 2'-(3-aminomethylbenzoate) esters from erythromycin B as a starting macrolide. 


\subsection{In Vitro Investigation of Synthesised Erythromycin B Derivatives against P. falciparum K1 Strain}

Erythromycin B and its derivatives were shown to possess anti-bacterial activity [17], but they have never been investigated as anti-malarials. Due to the fact that erythromycin B possesses acid stability [17], we hypothesised that they would show better anti-malarial activity when compared with erythromycin A. Therefore, we selected several derivatives of erythromycin B for evaluation: erythromycin B 9-oxime, 5-desosaminyl erythronolide B ethyl succinate, erythromycin B 2'-[3-(morpholinomethyl)benzoate], erythromycin B $2^{\prime}$-[3-(dimethylaminomethyl)benzoate], and 8-d-erythromycin B.

A $1 \%$ parasitised culture at ring stage was treated with the compounds for $72 \mathrm{~h}$ at concentrations of $3.05 \mathrm{nM}-200 \mu \mathrm{M}$ (four-fold serial dilution) against the P. falciparum K1 strain, and the growth was measured using the SYBR Green-based plate reader assay.

SYBR Green is a sensitive DNA stain that can bind to the double-stranded parasite DNA, and once intercalated, it becomes fluorescent [34]. SYBR Green assay offers a quick, inexpensive, and straightforward method to test parasites' susceptibility of anti-malarial drugs [35]. The assay takes the advantage of the fact that the parasite-host cells (healthy human mature erythrocytes) lack DNA; therefore, the fluorescence intensity reflects parasite growth.

The investigated compounds exhibited anti-malarial activities with micromolar $\mathrm{IC}_{50}$ values against the multi-drug-resistant $P$. falciparum strain K1 (Figure 2). Erythromycin B 9oxime gave an $\mathrm{IC}_{50}$ value of $146.0 \mu \mathrm{M}$; 5-desosaminyl erythronolide $B$ ethyl succinate gave an $\mathrm{IC}_{50}$ value of $68.6 \mu \mathrm{M}$; and 8-d-erythromycin B gave an $\mathrm{IC}_{50}$ of $86.8 \mu \mathrm{M}$. Both erythromycin $\mathrm{B}$ 2'-[3-(morpholinomethyl)benzoate] and erythromycin B 2'-[3-(dimethylaminomethyl)benzo ate] were less active, with $\mathrm{IC}_{50}$ values of more than $200 \mu \mathrm{M}$.

\subsection{Conformational Search Studies of the Investigated Derivatives of Erythromycin B in Chloroform}

3.3.1. Unconstrained Conformational Search of the Investigated Derivatives of Erythromycin B in Chloroform

We chose chloroform as a solvent because it was previously found that the most commonly used dielectric constant for proteins is 4 ; inside the protein according to the recent investigation, it is 6-7 [36]; and inside nucleic acids, it is 2 [37].

Folded-out and folded-in terms were defined by Everett et al. (1990) [38], and it was shown that erythromycin A mainly possesses characteristics of the folded-out conformational type [39]. The distances $(\AA)$ among the characteristic hydrogens for folded-out and folded-in conformations were measured for selected derivatives of erythromycin $B$ in chloroform as a solvent, which are given in Table 1, together with the energies of global minima and the number of times they repeat.

The global minimum of erythromycin 9-oxime in chloroform is neither folded out nor folded in, although the H4-H18 and H3-H8 distances correspond to a typical folded-in conformation. Erythromycin B 2'-[3-(morpholinomethyl) benzoate] in chloroform has a global minimum, which is a variation of a folded-out conformation. The global minimum of erythromycin B 2'-[3-(dimethylaminomethyl)benzoate] in chloroform is a typical foldedin conformation. 5-Desosaminyl erythronolide B ethyl succinate in chloroform shows a global minimum that is neither folded-out nor folded-in, but is different from the global minimum of erythromycin B 2'-[3-(morpholinomethyl) benzoate]. The global minimum of 8-d-erythromycin B is a folded-in conformation.

Previously, it was shown that the active conformation of the macrolide antibiotics bound weakly to bacterial ribosomes, such as clarithromycin, erythromycin A, and azithromycin [39], is mainly the folded-out conformation. None of the global minima for the investigated derivatives of erythromycin B is a typical folded-out conformation. Typical folded-out conformations for erythromycin B and 8-d-erythromycin B were found bound weakly to the bacterial ribosomes [27]; therefore, folded-out conformations were used for the docking analysis as the active conformations of the ligands-investigated derivatives of erythromycin $B$ (erythromycin B 9-oxime, erythromycin B 2'-[3-(morpholinomethyl) benzoate], erythromycin 
B 2'-[3-(dimethylaminomethyl)benzoate], 5-desosaminyl erythronolide B ethyl succinate, and 8- $d$-erythromycin B) to the complex consisting of $23 \mathrm{~S}$ rRNA and L4 protein from the apicoplast ribosome of $P$. falciparum previously constructed in silico [40]. The typical folded-out confor-

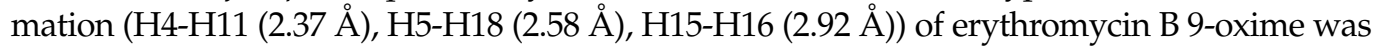
found with the energy $128.73 \mathrm{~kJ} / \mathrm{mol}$ and erythromycin B 2'-[3-(morpholinomethyl) benzoate]

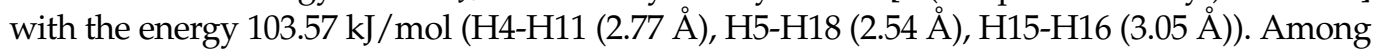
the first 50 conformations of the unconstrained conformational search of erythromycin B 2'-[3(dimethylaminomethyl)benzoate], the typical folded-out conformation was not found-the most similar was found with the energy $71.84 \mathrm{~kJ} / \mathrm{mol}(\mathrm{H} 4-\mathrm{H} 11(2.60 \AA), \mathrm{H} 5-\mathrm{H} 18(3.47 \AA)$, and H15-H16 (4.54 A))). 5-Desosaminyl erythronolide B ethyl succinate shows the typical folded-out conformation with the energy $110.47 \mathrm{~kJ} / \mathrm{mol}$ (H4-H11 (2.24 ̊), H5-H18 (2.64 ̊), H15-H16 $(3.06 \AA)$ ), and 8- $d$-erythromycin B with the energy $112.5 \mathrm{~kJ} / \mathrm{mol}$ (H4-H11 (2.82 $\AA)$, H5-H18 (2.61 $\AA$ ), and H15-H16 (3.13 $)$ ).

EryB 90

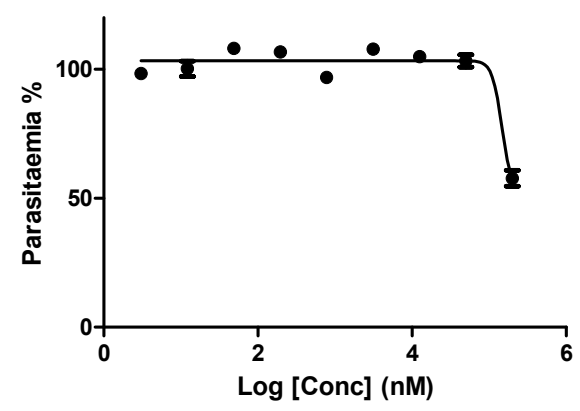

(a)

ЕВMмB

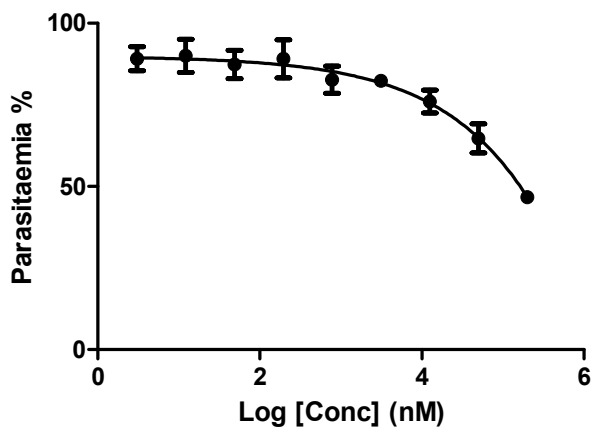

(c)

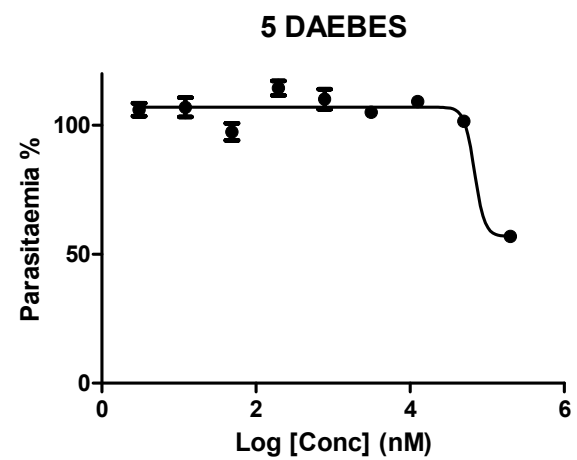

(b)

EBDAMB

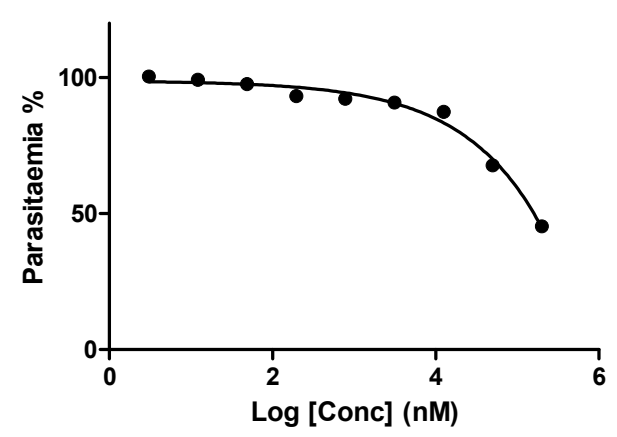

(d)

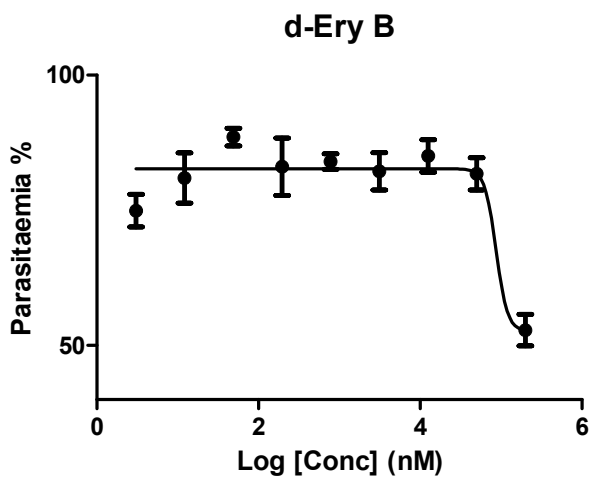

(e)

Figure 2. Dose-response curves for (a) erythromycin B 9-oxime (EryB 90), (b) 5-desosaminyl erythronolide B ethyl succinate (5DAEBES), (c) erythromycin B 2'-[3-(morpholinomethyl) benzoate] (EBMMB), (d) erythromycin B 2'-[3(dimethylaminomethyl)benzoate] (EBDAMB), and (e) 8-d-erythromycin B (d-Ery B). 
Table 1. Distances $(\AA)$ for the selected contacts of the global minima obtained in the unconstrained conformational search for selected derivatives of erythromycin $B$, and energies of global minima and times they repeat.

\begin{tabular}{|c|c|c|c|c|c|c|c|c|c|}
\hline \multirow[b]{2}{*}{ Compounds } & \multicolumn{2}{|c|}{ Global Minimum } & \multicolumn{7}{|c|}{ Distances (̊̊) } \\
\hline & $\begin{array}{l}\text { Energy } \\
(\mathrm{kJ} / \mathrm{mol})\end{array}$ & $\begin{array}{l}\text { Number } \\
\text { of } \\
\text { Repeats }\end{array}$ & H4-H11 & H15-H16 & H3-H8 & H3-H11 & H4-H18 & H5-H18 & H16-H17 \\
\hline $\begin{array}{l}\text { Erythromycin B 9-oxime } \\
\text { Erythromycin B }\end{array}$ & 124.27 & 3 & 6.70 & 4.59 & 2.20 & 5.18 & 2.77 & 3.46 & 2.93 \\
\hline $\begin{array}{l}2^{\prime}-[3-(\text { morpholinomethyl }) \\
\text { benzoate }]\end{array}$ & 102.62 & 2 & 3.02 & 2.88 & 5.67 & 3.92 & 4.08 & 2.57 & 3.83 \\
\hline $\begin{array}{l}\text { Erythromycin B 2'-[3- } \\
\text { (dimethylaminomethyl) } \\
\text { benzoate] }\end{array}$ & 70.16 & 4 & 4.79 & 3.69 & 2.34 & 2.15 & 2.51 & 3.48 & 2.57 \\
\hline $\begin{array}{l}\text { 5-Desosaminyl } \\
\text { erythronolide B ethyl } \\
\text { succinate }\end{array}$ & -118.56 & 1 & 3.82 & 3.05 & 6.93 & 4.72 & 3.55 & 3.44 & 4.99 \\
\hline 8-d-Erythromycin B & 111.13 & 1 & 3.97 & 3.76 & $2.35 *$ & 2.19 & 2.73 & 3.47 & 2.26 \\
\hline
\end{tabular}

3.3.2. Constrained Conformational Search of Erythromycin B 2'-[3-(dimethylaminomethyl)benzoate]

The constrained conformational search on erythromycin B 2'-[3-(dimethylaminomethyl) benzoate] in chloroform gave a global minimum with the energy $69.02 \mathrm{~kJ} / \mathrm{mol}$ repeated two times. It is a folded-out structure (H4-H11 (2.79 $)$ ), H5-H18 (2.54 $⿱$ )), and H15-H16 (3.04 $)$ )).

3.4. Docking Analysis of the Investigated Derivatives of Erythromycin B into In Silico Constructed Segment of the Exit Tunnel from the Apicoplast Ribosome of P. falciparum

The docking analysis of erythromycin B derivatives into in silico constructed exit tunnel from apicoplast ribosome from P. falciparum was complex. The majority of free or commercially available software for molecular docking are either suitable for proteins or RNAs as receptors, but not for complexes which contain both protein and RNA residues. We chose PatchDock for our docking analysis because it relies on different principles-on shape complementarity [26-28]—compared to other software.

For all docking analyses with derivatives of erythromycin B as ligands and complexes containing protein and three domains of $23 \mathrm{~S}$ rRNAs as receptors, results were characterised with the parameters presented in Table 2, such as score, area, and ACE.

Ten best results of performed molecular docking for each investigated erythromycin $B$ derivatives were subjected to FireDock refinement. Solution number, global energy, attractive van der Waals, repulsive van der Waals, and ACE for investigated erythromycin $B$ derivatives are given in Table 3.

Erythromycin B 9-oxime shows in the best-ranked solution after Firedock refinement without predetermined binding sites only interactions with nucleotides: $\pi-\sigma$ (violet circles), and $\pi$-Lone pair (light green circles) and $\pi$-alkyl (pink circles) (Figure 3). Erythromycin B 2'-[3-(morpholinomethyl)benzoate] under the same circumstances shows the solution with the following interactions with nucleotides: $\pi$ - $\sigma$ (violet circles), $\pi$-alkyl (pink circles), and carbon-hydrogen bond (light blue circles), as well as unfavourable bumps (red circles) (Figure 4).

Erythromycin B 2'-[3-(dimethylaminomethyl)benzoate] shows very similar behaviour regarding present interactions in the best-ranked solution structure after refinement using Firedock algorithm with the receptor: $\pi$-alkyl (pink circles), carbon hydrogen bond (light-blue circles), and an unfavourable bump (red circle) (Figure 5). 5-Desosaminyl erythronolide B ethyl succinate shows the following interactions with the nucleotides in the best-ranked solution: $\pi$ - $\sigma$ (violet circles), $\pi$-alkyl (pink circles), and carbon hydrogen bond (light-blue circles), as well as an unfavourable bump (red circle) (Figure 6). 
Table 2. Score, area, and ACE (atomic contact energy) of top ten results based on shape complementarity principles for docking analysis of investigated derivatives of erythromycin B with complex of protein and three domains of $23 \mathrm{~S}$ rRNA.

\begin{tabular}{|c|c|c|c|c|c|c|}
\hline \multirow{2}{*}{ Solutions } & \multirow{2}{*}{$\begin{array}{l}\text { Solution } \\
\text { Parameters }\end{array}$} & \multicolumn{5}{|c|}{ Derivatives } \\
\hline & & EryB 90 & EBMMB & EBDAMB & 5DAEBES & d-Ery B \\
\hline \multirow{3}{*}{1} & Score & 7332 & 7578 & 7362 & 6430 & 7132 \\
\hline & Area & 886.20 & 972.00 & 1012.70 & 740.40 & 800.00 \\
\hline & ACE & -341.11 & -477.95 & -490.63 & -324.01 & -337.27 \\
\hline \multirow{3}{*}{2} & Score & 7032 & 7388 & 7030 & 6222 & 6416 \\
\hline & Area & 839.20 & 951.20 & 745.90 & 739.90 & 754.20 \\
\hline & ACE & -339.59 & -419.55 & -275.08 & -467.41 & -362.32 \\
\hline \multirow{3}{*}{3} & Score & 6640 & 7376 & 6980 & 6162 & 6296 \\
\hline & Area & 845.50 & 896.30 & 785.80 & 865.40 & 900.70 \\
\hline & ACE & -277.37 & -424.72 & -376.62 & -404.81 & -342.87 \\
\hline \multirow{3}{*}{4} & Score & 6636 & 7276 & 6970 & 6110 & 6272 \\
\hline & Area & 700.10 & 966.70 & 827.10 & 840.20 & 749.90 \\
\hline & $\mathrm{ACE}$ & -326.43 & -462.36 & -437.15 & -442.39 & -264.42 \\
\hline \multirow{3}{*}{5} & Score & 6598 & 6834 & 6954 & 6056 & 6260 \\
\hline & Area & 896.20 & 898.30 & 860.40 & 727.70 & 836.30 \\
\hline & ACE & -408.91 & -461.77 & -418.69 & -365.69 & -280.40 \\
\hline \multirow{3}{*}{6} & Score & 6556 & 6830 & 6904 & 6000 & 6254 \\
\hline & Area & 704.80 & 814.00 & 858.30 & 759.10 & 701.70 \\
\hline & ACE & -379.30 & -311.01 & -431.74 & -286.73 & -325.53 \\
\hline \multirow{3}{*}{7} & Score & 6554 & 6826 & 6896 & 5972 & 6250 \\
\hline & Area & 719.30 & 891.70 & 816.60 & 831.00 & 736.90 \\
\hline & ACE & -336.11 & -334.69 & -362.42 & -319.28 & -386.86 \\
\hline \multirow{3}{*}{8} & Score & 6524 & 6824 & 6870 & 5952 & 6212 \\
\hline & Area & 802.30 & 885.40 & 812.00 & 716.10 & 722.80 \\
\hline & $\mathrm{ACE}$ & -464.79 & -330.79 & -351.92 & -351.59 & -353.71 \\
\hline \multirow{3}{*}{9} & Score & 6500 & 6726 & 6868 & 5896 & 6190 \\
\hline & Area & 786.90 & 754.70 & 851.10 & 646.80 & 670.10 \\
\hline & ACE & -389.76 & -291.68 & -349.78 & -267.87 & -306.69 \\
\hline \multirow{3}{*}{10} & Score & 6462 & 6722 & 6790 & 5892 & 6122 \\
\hline & Area & 714.60 & 1011.00 & 1014.50 & 693.60 & 804.90 \\
\hline & $\mathrm{ACE}$ & -372.85 & -489.58 & -487.56 & -183.95 & -351.11 \\
\hline
\end{tabular}

The docking results, followed by the refinement, provide a good explanation for the results of the anti-malarial tests. The highest number of unfavourable interactions is shown by erythromycin B 2'-[3-(morpholinomethyl)benzoate]; therefore, it is not surprising that this compound does not show any anti-malarial activity $\left(\mathrm{IC}_{50}>200 \mu \mathrm{M}\right)$. Erythromycin B 9-oxime does not show any unfavourable interactions, different from others, but it shows only five favourable interactions, the lowest number among the investigated erythromycin B derivatives. The highest number of favourable interactions was shown in case of 5-desosaminyl erythronolide B ethyl succinate; therefore, it is in good correlation with found $\mathrm{IC}_{50}$ value, which is the lowest among the investigated derivatives, i.e., the highest anti-malarial activity among the tested compounds. Erythromycin B 2'-[3(dimethylaminomethyl)benzoate] shows a higher number of favourable interactions (8) compared to 8- $d$-erythromycin B (7), but the last derivative shows interaction with more contribution ( $\pi$-Lone pair); therefore, this is the reason why 8- $d$-erythromycin $B$ shows better anti-malarial activity compared to erythromycin B 2'-[3-(dimethylaminomethyl)benzoate]. $\pi$-Lone pair is the interaction shared both between 8- $d$-erythromycin B and erythromycin B 9-oxime, but because of the higher number of favourable interactions shown by 8- $d$ erythromycin B, it shows better anti-malarial activity. 


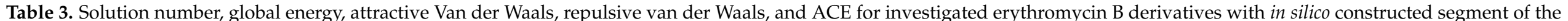
exit tunnel from the apicoplast ribosome of $P$. falciparum.

\begin{tabular}{|c|c|c|c|c|c|c|c|c|c|c|c|c|c|c|c|c|c|c|c|c|c|c|c|c|c|}
\hline \multirow{3}{*}{ Rank } & \multicolumn{25}{|c|}{ Derivatives } \\
\hline & \multicolumn{5}{|c|}{ eryB9O } & \multicolumn{5}{|c|}{ eryBMB } & \multicolumn{5}{|c|}{ eryBDA } & \multicolumn{5}{|c|}{ eryBD } & \multicolumn{5}{|c|}{ eryB8D } \\
\hline & SN & GE & AVdW & RVdW & ACE & SN & GE & AVdW & RVdW & ACE & SN & GE & AVdW & RVdW & ACE & SN & GE & AVdW & RVdW & ACE & SN & GE & AVdW & RVdW & ACE \\
\hline $\begin{array}{c}1 \\
2 \\
3 \\
4 \\
5 \\
6 \\
7 \\
8 \\
9 \\
10\end{array}$ & $\begin{array}{l}10 \\
9 \\
1 \\
2 \\
8 \\
6 \\
4 \\
7 \\
3 \\
5\end{array}$ & $\begin{array}{l}-63.18 \\
-60.65 \\
-60.28 \\
-59.82 \\
-53.61 \\
-47.33 \\
-44.88 \\
-42.39 \\
-23.15 \\
-15.07\end{array}$ & $\begin{array}{l}-23.29 \\
-24.69 \\
-24.59 \\
-23.60 \\
-23.03 \\
-16.88 \\
-16.35 \\
-16.63 \\
-7.92 \\
-9.36\end{array}$ & $\begin{array}{l}9.23 \\
9.32 \\
8.05 \\
12.36 \\
16.31 \\
9.54 \\
7.59 \\
9.09 \\
2.81 \\
7.03\end{array}$ & $\begin{array}{l}-22.58 \\
-20.27 \\
-19.29 \\
-21.84 \\
-21.13 \\
-18.68 \\
-16.79 \\
-15.56 \\
-9.12 \\
-4.80\end{array}$ & $\begin{array}{c}5 \\
3 \\
4 \\
9 \\
7 \\
6 \\
2 \\
10 \\
8 \\
1\end{array}$ & $\begin{array}{l}-74.06 \\
-55.61 \\
-50.21 \\
-44.94 \\
-44.11 \\
-41.75 \\
-30.70 \\
-29.42 \\
-21.96 \\
-15.89\end{array}$ & $\begin{array}{l}-28.32 \\
-21.65 \\
-26.49 \\
-18.35 \\
-24.22 \\
-23.33 \\
-25.80 \\
-18.97 \\
-11.50 \\
-27.10\end{array}$ & $\begin{array}{l}8.97 \\
7.65 \\
26.04 \\
7.22 \\
27.44 \\
15.91 \\
40.54 \\
19.66 \\
4.54 \\
72.48\end{array}$ & $\begin{array}{l}-24.41 \\
-19.85 \\
-19.84 \\
-15.85 \\
-18.84 \\
-14.88 \\
-17.23 \\
-12.45 \\
-5.58 \\
-21.55\end{array}$ & $\begin{array}{l}5 \\
4 \\
8 \\
10 \\
6 \\
2 \\
3 \\
7 \\
1 \\
9\end{array}$ & $\begin{array}{l}-57.60 \\
-52.66 \\
-51.82 \\
-51.58 \\
-48.66 \\
-48.50 \\
-45.67 \\
-41.62 \\
-40.86 \\
-24.27\end{array}$ & $\begin{array}{l}-23.55 \\
-20.91 \\
-21.02 \\
-28.90 \\
-23.05 \\
-18.58 \\
-22.70 \\
-19.57 \\
-25.65 \\
-8.63\end{array}$ & $\begin{array}{l}13.89 \\
14.62 \\
4.11 \\
26.43 \\
16.02 \\
4.20 \\
23.01 \\
13.90 \\
23.11 \\
3.70\end{array}$ & $\begin{array}{l}-21.13 \\
-20.77 \\
-15.61 \\
-20.68 \\
-19.41 \\
-15.64 \\
-19.13 \\
-16.31 \\
-15.79 \\
-9.54\end{array}$ & $\begin{array}{l}2 \\
1 \\
8 \\
7 \\
3 \\
10 \\
9 \\
5 \\
4 \\
6\end{array}$ & $\begin{array}{l}-67.89 \\
-52.42 \\
-49.83 \\
-47.89 \\
-45.82 \\
-44.62 \\
-38.29 \\
-38.09 \\
-34.84 \\
-32.26\end{array}$ & $\begin{array}{l}-25.26 \\
-20.56 \\
-22.88 \\
-23.46 \\
-19.87 \\
-2.28 \\
-17.57 \\
-21.25 \\
-14.83 \\
-20.80\end{array}$ & $\begin{array}{l}11.31 \\
9.31 \\
22.20 \\
14.09 \\
8.91 \\
8.79 \\
17.63 \\
25.36 \\
7.62 \\
22.81\end{array}$ & $\begin{array}{l}-24.74 \\
-18.29 \\
-20.92 \\
-16.53 \\
-15.22 \\
-14.04 \\
-14.30 \\
-18.31 \\
-12.25 \\
-13.81\end{array}$ & $\begin{array}{l}6 \\
1 \\
2 \\
8 \\
9 \\
7 \\
4 \\
3 \\
5 \\
10\end{array}$ & $\begin{array}{l}-63.40 \\
-61.51 \\
-48.35 \\
-46.70 \\
-45.24 \\
-42.49 \\
-40.76 \\
-33.22 \\
-24.99 \\
-11.66\end{array}$ & $\begin{array}{l}-26.31 \\
-23.48 \\
-21.82 \\
-20.56 \\
-15.63 \\
-17.24 \\
-19.02 \\
-14.06 \\
-12.77 \\
-22.26\end{array}$ & $\begin{array}{l}9.46 \\
8.48 \\
17.42 \\
18.10 \\
3.87 \\
11.94 \\
11.57 \\
6.78 \\
12.30 \\
59.71\end{array}$ & $\begin{array}{l}-20.67 \\
-20.95 \\
-18.82 \\
-19.11 \\
-15.69 \\
-16.47 \\
-15.62 \\
-13.20 \\
-11.45 \\
-16.76\end{array}$ \\
\hline
\end{tabular}

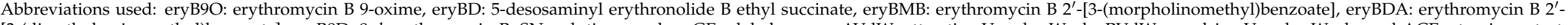

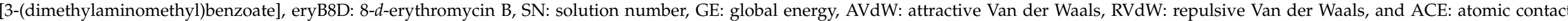
energy. 


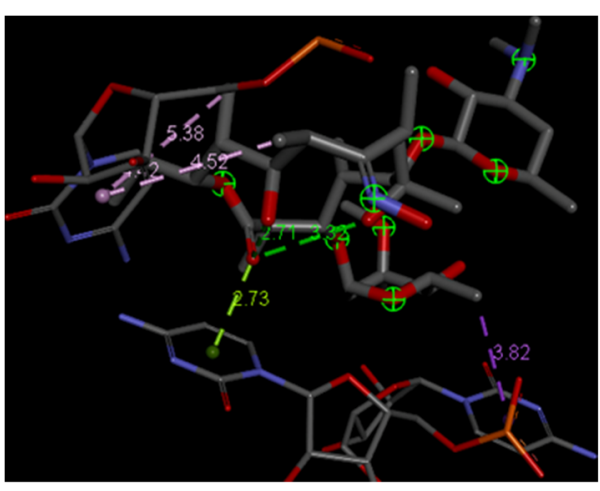

(a)

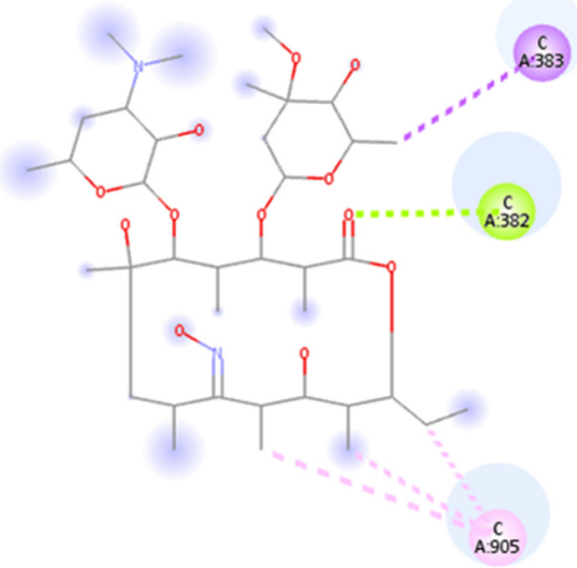

(b)

Figure 3. (a) Graphical representation of the obtained interactions between erythromycin B 9-oxime and the segment of the exit tunnel from apicoplast ribosome of P. falciparum with distances in $\AA$; (b) 2D diagram of receptor-ligand interactions.

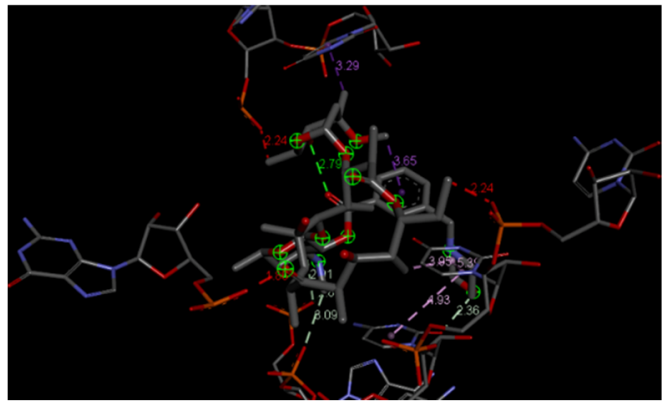

(a)

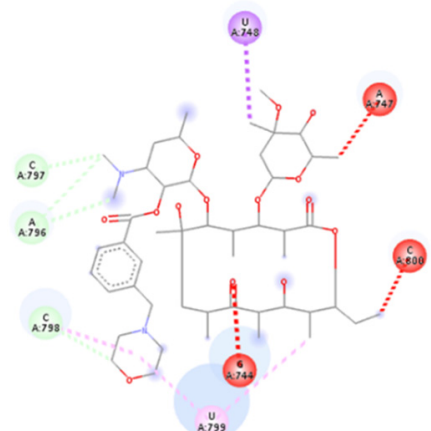

(b)

Figure 4. (a) Graphical representation of the obtained interactions between erythromycin B 2'-[3(morpholinomethyl)benzoate] and the segment of the exit tunnel from apicoplast ribosome of $P$. falciparum with distances in $\AA$; (b) 2D diagram of receptor-ligand interactions.

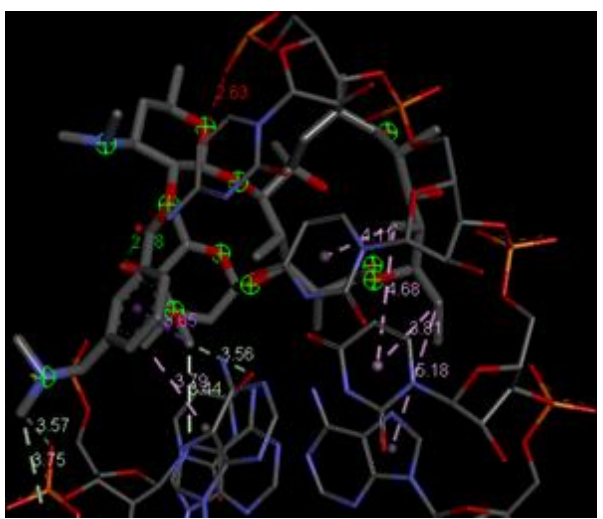

(a)

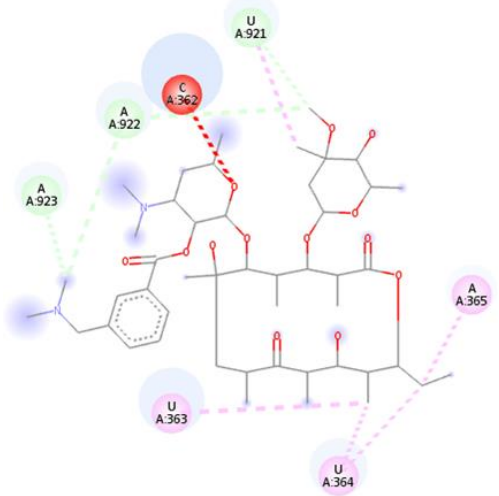

(b)

Figure 5. (a) Graphical representation of the obtained interactions between erythromycin B 2'-[3(dimethylaminomethyl)benzoate] and the segment of the exit tunnel from apicoplast ribosome of $P$. falciparum with distances in $\AA$; (b) 2D diagram of receptor-ligand interactions.

8-d-Erythromycin B shows some general patterns regarding the interactions with the nucleotides from the receptor-in silico made segment of the exit tunnel from apicoplast 
ribosome of P. falciparum: unfavourable bump (red circle), carbon hydrogen bond (light blue circle), $\pi$-Lone pair (light green circle), and $\pi$-alkyl (pink circle) (Figure 7).

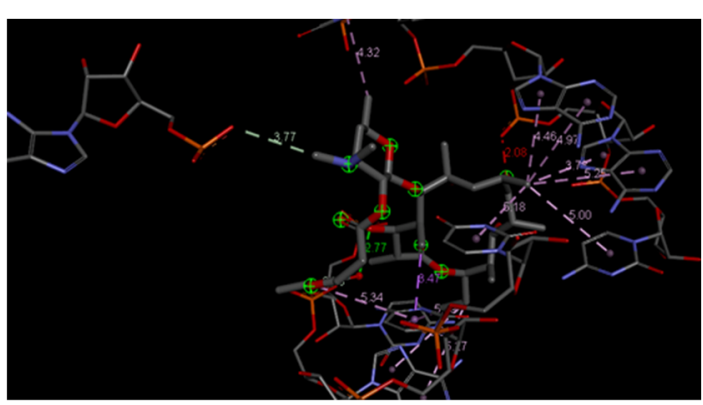

(a)

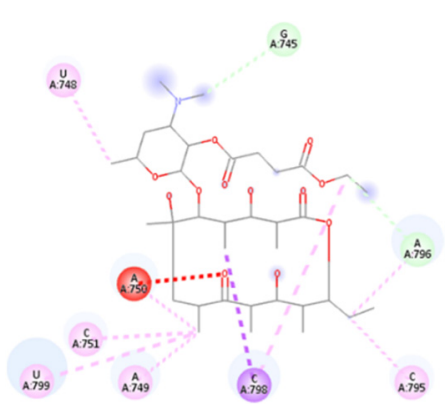

(b)

Figure 6. (a) Graphical representation of the obtained interactions between 5-desosaminyl erythronolide B ethyl succinate and the segment of the exit tunnel from apicoplast ribosome of $P$. falciparum with distances in $\AA$; (b) 2D diagram of receptor-ligand interactions.

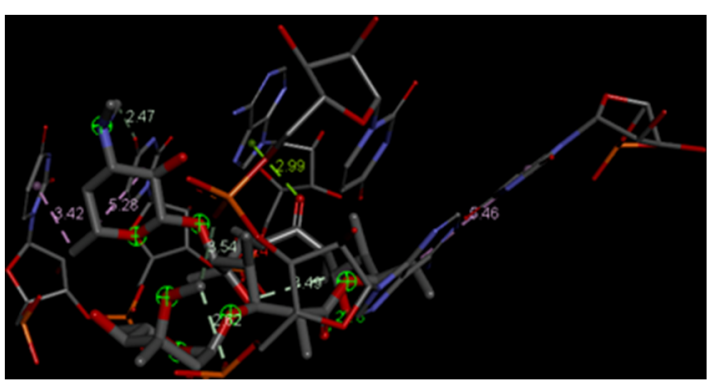

(a)

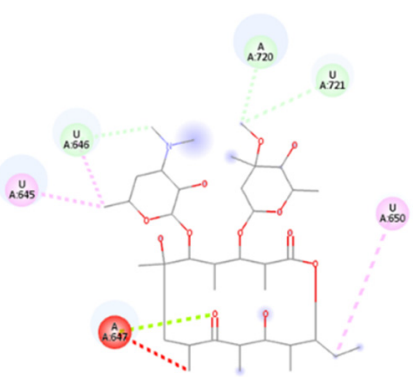

(b)

Figure 7. (a) Graphical representation of the obtained interactions between 8- $d$-erythromycin B and the segment of the exit tunnel from apicoplast ribosome of $P$. falciparum with distances in $\AA$; (b) 2D diagram of receptor-ligand interactions.

It can be speculated that the small number of favourable interactions or the presence of unfavourable interactions is the reason for weak anti-malarial activity of investigated derivatives of erythromycin B. Molecular docking can also be a good tool for the prediction of anti-malarial activity of derivatives with previously undetermined anti-malarial activity. In the future, we will broaden our investigation using both in silico tools and experimental results.

\section{Conclusions}

Five derivatives of erythromycin B were synthesised and evaluated for their antimalarial activity against multi-drug-resistant $\mathrm{K} 1$ strain of $P$. falciparum. They do not show significant anti-malarial activity, ranging from $68.6 \mu \mathrm{M}$ for 5-desosaminyl erythronolide $\mathrm{B}$ ethyl succinate to more than $200 \mu \mathrm{M}$ for erythromycin B 2'-[3-(morpholinomethyl)benzoate] and erythromycin B 2'-[3-(dimethylaminomethyl)benzoate]. Performed conformational search (unconstrained for all and constrained only for erythromycin B 2'-[3-(dimethylamino methyl)benzoate]) in chloroform gave the most probable folded-out structures which were used as active conformations for molecular docking. Molecular docking results provided an explanation for the order of anti-malarial activity amongst the investigated derivatives of erythromycin B. 
Author Contributions: Conceptualisation, N.N., S.F., J.B. and B.A.; methodology, N.N., S.F., J.B. and B.A.; formal analysis, P.K.B., R.N.M. and B.A.; investigation, P.K.B., R.N.M. and B.A.; resources, B.A.; data curation, P.K.B., R.N.M., N.N., S.F., J.B. and B.A.; writing-original draft preparation, B.A.; writing-review and editing: P.K.B., R.N.M., N.N., S.F., J.B. and B.A.; visualization, P.K.B., R.N.M. and B.A.; supervision, N.N., S.F., J.B. and B.A.; project administration, N.N., S.F., J.B. and B.A.; funding acquisition, B.A. All authors have read and agreed to the published version of the manuscript.

Funding: Biljana Arsic wants to thank for the financial support for the work to Ministry of Education, Science and Technological Development of Republic of Serbia (contract number 451-03-9/202114/200124). Rachael Magwaza thanks Aspen Pharmacare (SA) and National Research Foundation (grant no.: 107881) for sponsorship.

Institutional Review Board Statement: Not applicable.

Informed Consent Statement: Not applicable.

Data Availability Statement: All data necessary for understanding of the research are present in the manuscript. Additional data related to molecular modelling and NMR analyses of synthesised compounds can be obtained from authors upon the request.

Conflicts of Interest: The authors declare no conflict of interest.

\section{References}

1. World Health Organization. Malaria. Available online: https://www.who.int/news-room/fact-sheets/detail/malaria (accessed on 13 November 2021).

2. Ford, J.M.; Hait, W.N. Pharmacology of drugs that alter multidrug resistance in cancer. Pharmacol. Rev. 1990, 42, 155-199. [PubMed]

3. Menezes, M.S.; Kirchgatter, K.; Di Santi, S.M.F.; Savalli, C.; Monteiro, F.G.; Paula, G.A.; Ferreira, E.I. In vitro evaluation of erythromycin in chloroquine resistant Brazilian P. falciparum freshly isolates: Modulation effect and antimalarial activity evidence. Rev. Inst. Med. Trop. São Paulo 1999, 41, 249-253. [CrossRef]

4. Hofsli, E.; Nissen-Meyer, J. Effect of erythromycin and tumour necrosis factor on the drug resistance of multidrug-resistant cells: Reversal of drug resistance by erythromycin. Int. J. Cancer 1989, 43, 520-525. [CrossRef]

5. Hofsli, E.; Nissen-Meyer, J. Reversal of multidrug resistance by lipophilic drugs. Cancer Res. 1990, 50, 3997-4002. [PubMed]

6. Robinson, B.L.; Warhurst, D.C. Antimalarial activity of erythromycin. Trans. R. Soc. Trop. Med. Hyg. 1972, $66,525$.

7. Gaillard, T.; Madamet, M.; Tsombeng, F.F.; Dormoi, J. Antibiotics in malaria therapy: Which antibiotics except tetracyclines and macrolides may be used against malaria? Malar. J. 2016, 15, 556. [CrossRef]

8. Sowunmi, A.; Gbotosho, G.O.; Fateye, B.A.; Adedeji, A.A. Predictors of the failure of treatment with trimethoprimsulfamethoxazole in children with uncomplicated, Plasmodium falciparum malaria. Ann. Trop. Med. Parasitol. 2006, 100, $205-211$. [CrossRef] [PubMed]

9. Mermin, J.; Ekwaru, J.P.; Liechty, C.A.; Were, W.; Downing, R.; Ransom, R.; Weidle, P.; Lule, J.; Coutinho, A.; Solberg, P. Effect of co-trimoxazole prophylaxis, antiretroviral therapy, and insecticide-treated bednets on the frequency of malaria in HIV-1-infected adults in Uganda: A prospective cohort study. Lancet 2006, 367, 1256-1261. [CrossRef]

10. Manyando, C.; Njunju, E.M.; Mwakazanga, D.; Chongwe, G.; Mkandawire, R.; Champo, D.; Mulenga, M.; De Crop, M.; Claeys, Y.; Ravinetto, R.M.; et al. Safety of daily co-trimoxazole in pregnancy in an area of changing malaria epidemiology: A phase $3 \mathrm{~b}$ randomized controlled clinical trial. PLoS ONE 2014, 9, 96017.

11. Corbett, E.L.; Churchyard, G.J.; Charalambos, S.; Samb, B.; Moloi, V.; Clayton, T.C.; Grant, A.D.; Murray, J.; Hayes, R.J.; De Cock, K.M. Morbidity and mortality in South African gold miners: Impact of untreated disease due to human immunodeficiency virus. Clin. Infect. Dis. 2002, 34, 1251-1258. [CrossRef]

12. Bukvić Krajačić, M.; Perić, M.; Smith, K.S.; Ivezić Schonfeld, Z.; Žiher, D.; Fajdetić, A.; Kujundžić, N.; Schonfeld, W.; Landek, G.; Padovan, J.; et al. Synthesis, structure-activity relationship, and antimalarial activity of ureas and thioureas of 15-membered azalides. J. Med. Chem. 2011, 54, 3595-3605. [CrossRef] [PubMed]

13. Perić, M.; Fajdetić, A.; Rupčić, R.; Alihodžić, S.; Žiher, D.; Bukvić Krajačić, M.; Smith, K.S.; Ivezić-Schonfeld, Z.; Padovan, J.; Landek, G.; et al. Antimalarial activity of $9 \mathrm{a}-\mathrm{N}$ substituted 15 -membered azalides with improved in vitro and in vivo activity over azithromycin. J. Med. Chem. 2012, 55, 1389-1401. [CrossRef]

14. Gaillard, T.; Dormoi, J.; Madamet, M.; Pradines, B. Macrolides and associated antibiotics based on similar mechanism of action like lincosamides in malaria. Malar. J. 2016, 15, 85. [CrossRef] [PubMed]

15. Sidhu, A.B.; Sun, Q.; Nkrumah, L.J.; Dunne, M.W.; Sacchettini, J.C.; Fidock, D.A. In vitro efficacy, resistance selection, and structural modeling studies implicate the malarial parasite apicoplast as the target of azithromycin. J. Biol. Chem. 2007, 282, 2494-2504. [CrossRef] 
16. Ohrt, C.; Willingmyre, G.D.; Lee, P.; Knirsch, C.; Milhous, W. Assessment of azithromycin in combination with other antimalarial drugs against Plasmodium falciparum in vitro. Antimicrob. Agents Chemother. 2002, 46, 2518-2524. [CrossRef] [PubMed]

17. Mordi, M.N.; Pelta, M.D.; Boote, V.; Morris, G.A.; Barber, J. Acid-catalysed degradation of clarithromycin and erythromycin B: A comparative study using NMR spectroscopy. J. Med. Chem. 2000, 43, 467-474. [CrossRef] [PubMed]

18. Cachet, T.; Roets, E.; Hoogmartens, J.; Vanderhaeghe, H. Separation of novel derivatives from commercial erythromycin samples by thin layer chromatography. J. Chrom. 1987, 403, 343-349. [CrossRef]

19. Barjat, H.; Morris, G.A.; Smart, S.; Swanson, A.G.; William, S.C.R. Reference deconvolution using multiplet reference signal. J. Mag. Res. Ser. A 1995, 116, 206-214. [CrossRef]

20. Barjat, H.; Morris, G.A.; Smart, S.; Swanson, A.G.; William, S.C.R. High-resolution diffusion-ordered 2D spectroscopy (HR-DOSY). J. Mag. Res. Ser. B 1995, 108, 171-172.

21. Morris, G.A. Diffusion-Ordered Spectroscopy (DOSY). Encyclopedia of Nuclear Magnetic Resonance: Advances in NMR; John Wiley and Sons: Chichester, UK, 2002; pp. 35-44.

22. Gasc, J.C.; D'Ambrieres, S.G.; Lutz, A.; Chantot, J.F. New ether oxime derivatives of erythromycin A: A structure activity relationship study. J. Antibiot. 1991, 44, 313-331. [CrossRef]

23. Watanabe, Y.; Morimoto, S.; Adachi, T.; Kashimura, M.; Asaka, T. Chemical modification of erythromycins IX. Selective methylation at the C-6 hydroxyl group of erythromycin A oxime derivatives and preparation of clarithromycin. J. Antibiot. 1993, 46, 647-660. [CrossRef] [PubMed]

24. Jensen, E.; Bundgaard, H.; Falch, E. Design of a water-soluble, solution-stable and biolabile prodrug of metronidazole for parenteral administration: $N$-substituted aminomethylbenzoate esters. Int. J. Pharm. 1990, 58, 143-153. [CrossRef]

25. Bhadra, P.K.; Morris, G.A.; Barber, J. Design, synthesis, and evaluation of stable and taste-free erythromycin proprodrugs. J. Med. Chem. 2005, 48, 3878-3884. [CrossRef] [PubMed]

26. Hassanzadeh, A.; Gorry, P.A.; Morris, G.A.; Barber, J. Pediatric erythromycins: A comparison of the properties of erythromycins A and B 2'-ethyl succinates. J. Med. Chem. 2006, 49, 6334-6342. [CrossRef]

27. Bhadra, P.K.; Hassanzadeh, A.; Arsic, B.; Allison, D.G.; Morris, G.A.; Barber, J. Enhancement of the properties of a drug by mono-deuteriation: Reduction of acid-catalysed formation of a gut-motilide enol ether from 8-deuterio-erythromycin B. Org. Biomol. Chem. 2016, 14, 6289-6296. [CrossRef] [PubMed]

28. Duhovny, D.; Nussinov, R.; Wolfson, H.J. Efficient Unbound Docking of Rigid Molecules. In Proceedings of the 2nd Workshop on Algorithms in Bioinformatics (WABI), Rome, Italy, 16-21 September 2002; Lecture Notes in Computer Science 2452. Guigo, G., Ed.; Springer: Berlin/Heidelberg, Germany, 2002; pp. 185-200.

29. Schneidman-Duhovny, D.; Inbar, Y.; Polak, V.; Shatsky, M.; Halperin, I.; Benyamini, H.; Barzilai, A.; Dror, O.; Haspel, N.; Nussinov, R.; et al. Taking geometry to its edge: Fast unbound rigid (and hinge-bent) docking. Proteins 2003, 52, 107-112. [CrossRef]

30. Schneidman-Duhovny, D.; Inbar, Y.; Nussinov, R.; Wolfson, H.J. PatchDock and SymmDock: Servers for rigid and symmetric docking. Nucleic Acids Res. 2005, 33, W363-W367. [CrossRef]

31. Andrusier, N.; Nussinov, R.; Wolfson, H.J. FireDock: Fast Interaction Refinement in Molecular Docking. Proteins 2007, 69, 139-159. [CrossRef]

32. Mashiach, E.; Schneidman-Duhovny, D.; Andrusier, N.; Nussinov, R.; Wolfson, H.J. FireDock: A web server for fast interaction refinement in molecular docking. Nucleic Acids Res. 2008, 36, W229-W232. [CrossRef]

33. Pranab, B. Erythromycin B: An Old Drug for the New Millennium. Ph.D. Thesis, The University of Manchester, Manchester, UK, 2003.

34. Vossen, M.G.; Pferschy, S.; Chiba, P.; Noedl, H. The SYBR green I malaria drug sensitivity assay: Performance in low parasitemia samples. Am. J. Trop. Med. Hyg. 2010, 82, 398-401. [CrossRef]

35. Rason, M.A.; Randriantsoa, T.; Andrianantenaina, H.; Ratsimbasoa, A.; Menard, D. Performance and reliability of the SYBR Green I based assay for the routine monitoring of susceptibility of Plasmodium falciparum clinical isolates. Trans. R. Soc. Trop. Med. Hyg. 2008, 102, 346-351. [CrossRef]

36. Li, L.; Li, C.; Zhang, Z.; Alexov, E. On the dielectric "constant" of proteins: Smooth dielectric function for macromolecular modeling and its implementation in DelPhi. J. Chem. Theory Comput. 2013, 9, 2126-2136. [CrossRef]

37. Xi, K.; Wang, F.-H.; Xiong, G.; Zhang, Z.-L.; Tan, Z.-J. Competitive binding of $\mathrm{Mg}^{2+}$ and $\mathrm{Na}^{+}$ions to nucleic acids: From helices to tertiary structures. Biophys. J. 2018, 114, 1776-1790. [CrossRef]

38. Everett, J.R.; Tyler, J.W. The conformational analysis of erythromycin A. J. Chem. Soc. Perkin Trans. 2 1987, 11, 1659-1667. [CrossRef]

39. Arsic, B.; Awan, A.; Brennan, R.J.; Aguilar, J.A.; Ledder, R.; McBain, A.J.; Regan, A.C.; Barber, J. Theoretical and experimental investigation on clarithromycin, erythromycin A and azithromycin and descladinosyl derivatives of clarithromycin and azithromycin with 3-O substitution as antibacterial agents. Med. Chem. Commun. 2014, 5, 1347-1354. [CrossRef]

40. Arsic, B.; Barber, J. In silico study on the apicoplast L4 ribosomal protein and three domains from $23 \mathrm{~S}$ rRNA from Plasmodium falciparum and comparison with the existing cocrystal structures. Chem. Naissensis 2019, 2, 50-61. 